4

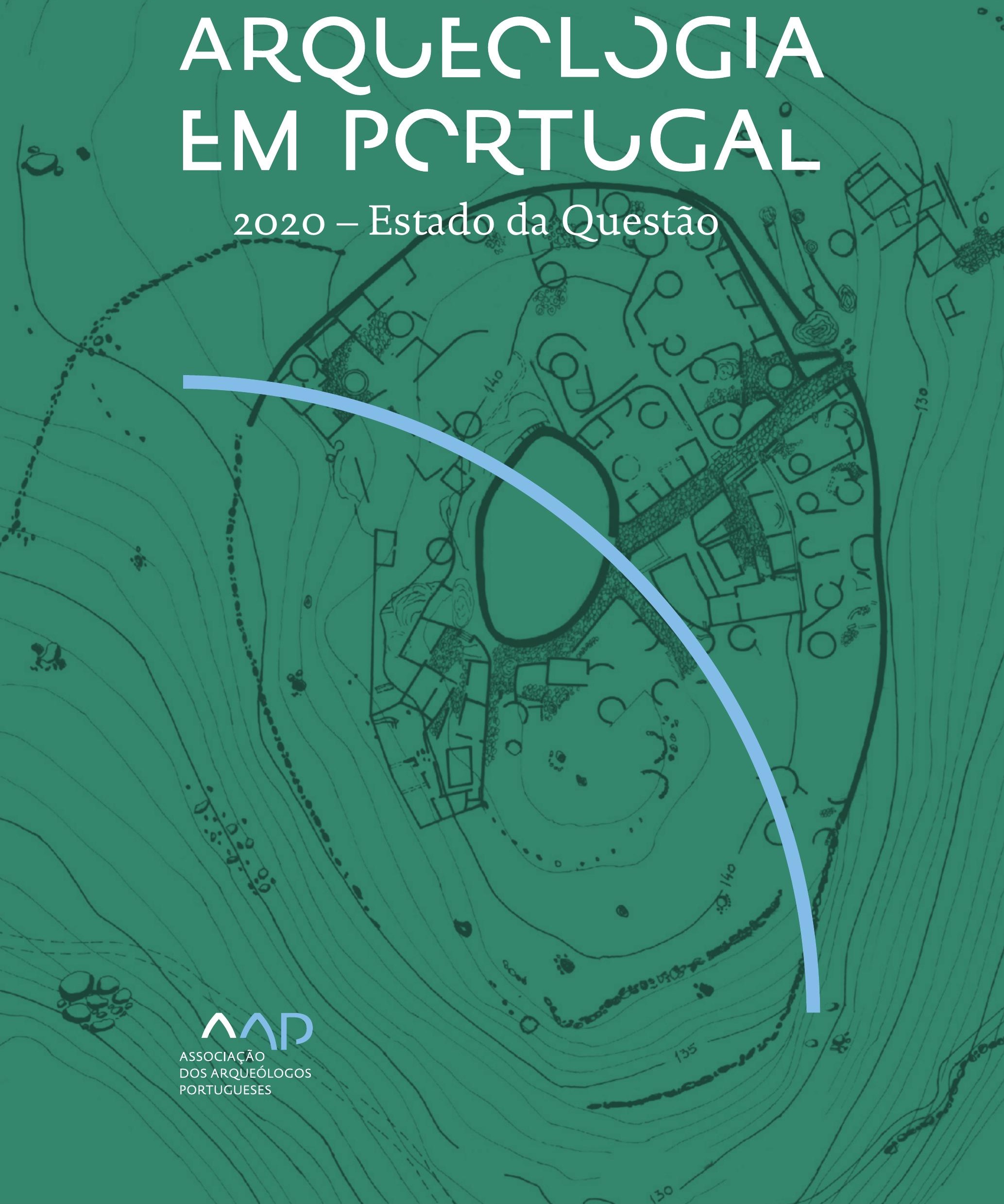


Coordenação editorial: José Morais Arnaud, César Neves e Andrea Martins Design gráfico: Flatland Design

AAP - ISBN: 978-972-9451-89-8

CITCEM - ISBN: 978-989-8970-25-1

Associação dos Arqueólogos Portugueses e CITCEM

Lisboa, 2020

O conteúdo dos artigos é da inteira responsabilidade dos autores. Sendo assim a Associação dos Arqueólogos Portugueses declina qualquer responsabilidade por eventuais equívocos ou questões de ordem ética e legal.

Desenho de capa:

Planta do castro de Monte Mozinho (Museu Municipal de Penafiel).

\section{$\hat{\wedge} \mathrm{P}$}

DOS ARQUEÓLOGOS PORTUGUESES

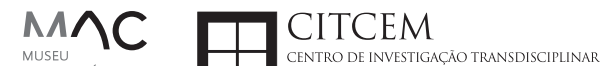
MUSEU
ARQUELLÓGICO
DO CARMO
U.PORTO

FLUP FACULDADE DE LETRAS
UNIVERSIDADE DO PORTO

Apoio

EC para a Ciência 


\section{Índice}

15 Prefácio

José Morais Arnaud

\section{Historiografia e Teoria}

17 Território, comunidade, memória e emoção: a contribuição da história da arqueologia (algumas primeiras e breves reflexões)

Ana Cristina Martins

25 Como descolonizar a arqueologia portuguesa?

Rui Gomes Coelho

41 Arqueologia e Modernidade: uma revisitação pessoal e breve de alguns aspetos da obra homónima de Julian Thomas de 2004

Vítor Oliveira Jorge

57 Dados para a História das Mulheres na Arqueologia portuguesa, dos finais do século XIX aos inícios do século XX: números, nomes e tabelas

Filipa Dimas / Mariana Diniz

73 Retractos da arqueologia portuguesa na imprensa: (in)visibilidades no feminino

Catarina Costeira / Elsa Luís

85 Arqueologia e Arqueólogos no Norte de Portugal Jacinta Bugalhão

101 Vieira Guimarães (1864-1939) e a arqueologia em Tomar: uma abordagem sobre o território e as gentes

João Amendoeira Peixoto / Ana Cristina Martins

115 Os memoráveis? A arqueologia algarvia na imprensa nacional e regional na presente centúria (2001-2019): características, visões do(s) passado(s) e a arqueologia

enquanto marca

Frederico Agosto / João Silva

129 A Evolução da Arqueologia Urbana e a Valorização Patrimonial no Barlavento Algarvio: Os casos de Portimão e Silves

Artur Mateus / Diogo Varandas / Rafael Boavida

\section{Gestão, Valorização e Salvaguarda do Património}

145 O Caderno Reivindicativo e as condições de trabalho em Arqueologia Miguel Rocha / Liliana Matias Carvalho / Regis Barbosa / Mauro Correia / Sara Simões / Jacinta Bugalhão / Sara Brito / Liliana Veríssimo Carvalho / Richard Peace / Pedro Peça / Cézer Santos

155 Os Estudos de Impacte Patrimonial como elemento para uma estratégia sustentável de minimização de impactes no âmbito de reconversões agrícolas Tiago do Pereiro

165 Salvaguarda de Património arqueológico em operações florestais: gestão e sensibilização Filipa Bragança / Gertrudes Zambujo / Sandra Lourenço / Belém Paiva / Carlos Banha / Frederico Tatá Regala / Helena Moura / Jacinta Bugalhão / João Marques / José Correia / Pedro Faria / Samuel Melro

179 Os valores do Património: uma investigação sobre os Sítios Pré-históricos de Arte Rupestre do Vale do Rio Côa e de Siega Verde José Paulo Francisco 
189 Conjugando recursos arqueológicos e naturais para potenciar as visitas ao Geoparque Litoral de Viana do Castelo (Noroeste de Portugal)

Hugo A. Sampaio / Ana M.S. Bettencourt / Susana Marinho / Ricardo Carvalhido

203 Áreas de Potencial Arqueológico na Região do Médio Tejo: Modelo Espacial Preditivo Rita Ferreira Anastácio / Ana Filipa Martins / Luiz Oosterbeek

223 Património Arqueológico e Gestão Territorial: O contributo da Arqueologia para a revisão do PDM de Avis

Ana Cristina Ribeiro

237 A coleção arqueológica do extinto Museu Municipal do Porto - Origens, Percursos e Estudos

Sónia Couto

251 Valpaços - uma nova carta arqueológica

Pedro Pereira / Maria de Fátima Casares Machado

263 Arqueologia na Cidade de Peniche

Adriano Constantino / Luís Rendeiro

273 Arqueologia Urbana: a cidade de Lagos como caso de Estudo Cátia Neto

285 Estratégias de promoção do património cultural subaquático nos Açores. O caso da ilha do Faial

José Luís Neto / José Bettencourt / Luís Borges / Pedro Parreira

297 Carta Arqueológica da Cidade Velha: Uma primeira abordagem

Jaylson Monteiro / Nireide Tavares / Sara da Veiga / Claudino Ramos / Edson Brito /

Carlos Carvalho / Francisco Moreira / Adalberto Tavares

311 Antropologia Virtual: novas metodologias para a análise morfológica e funcional Ricardo Miguel Godinho / Célia Gonçalves

\section{Didáctica da Arqueologia}

327 Como os projetos de Arqueologia podem contribuir para uma comunidade culturalmente mais consciente Alexandra Figueiredo / Claúdio Monteiro / Adolfo Silveira / Ricardo Lopes

337 Educação Patrimonial - Um cidadão esclarecido é um cidadão ativo! Ana Paula Almeida

351 A aproximação da Arqueologia à sala de aula: um caso de estudo no $3^{\circ}$ ciclo do Ensino Básico Luís Serrão Gil

363 Arqueologia 3.o - Pensar e comunicar a Arqueologia para um futuro sustentável Mónica Rolo

377 “Conversa de Arqueólogos" - Divulgar a Arqueologia em tempos de Pandemia Diogo Teixeira Dias

389 Escola Profissional de Arqueologia: desafios e oportunidades Susana Nunes / Dulcineia Pinto / Júlia Silva / Ana Mascarenhas

399 Os Museus de Arqueologia e os Jovens: a oferta educativa para o público adolescente Beatriz Correia Barata / Leonor Medeiros

411 O museu universitário como mediador entre a ciência e a sociedade: o exemplo da secção de arqueologia no Museu de História Natural e da Ciência da Universidade do Porto (MHNC-UP)

Rita Gaspar 
421 Museu de Lanifícios: Real Fábrica de Panos. Atividades no âmbito da Arqueologia Beatriz Correia Barata / Rita Salvado

427 Arqueologia Pública e o caso da localidade da Mata (Torres Novas) Cláudia Manso / Ana Rita Ferreira / Cristiana Ferreira / Vanessa Cardoso Antunes

431 Do sítio arqueológico ao museu: um percurso (também) didático Lídia Fernandes

447 Estão todos convidados para a Festa! E para dançar também... O projecto do Serviço Educativo do Museu Arqueológico do Carmo na $5^{\underline{a}}$ Edição da Festa da Arqueologia Rita Pires dos Santos

459 O “Clã de Carenque”, um projeto didático de arqueologia Eduardo Gonzalez Rocha

469 Mediação cultural: peixe que puxa carroça nas Ruínas Romanas de Troia Inês Vaz Pinto / Ana Patrícia Magalhães / Patrícia Brum / Filipa Santos

481 Didática Arqueológica, experiências do Projeto Mértola Vila Museu Maria de Fátima Palma / Clara Rodrigues / Susana Gómez / Lígia Rafael

\section{Arte Rupestre}

497 Os inventários de arte rupestre em Portugal Mila Simões de Abreu

513 O projeto FIRST-ART - conservação, documentação e gestão das primeiras manifestações de arte rupestre no Sudoeste da Península Ibérica: as grutas do Escoural e Maltravieso Sara Garcês / Hipólito Collado / José Julio García Arranz / Luiz Oosterbeek / António Carlos Silva / Pierluigi Rosina / Hugo Gomes / Anabela Borralheiro Pereira / George Nash / Esmeralda Gomes / Nelson Almeida / Carlos Carpetudo

523 Trabalhos de documentação de arte paleolítica realizados no âmbito do projeto PalæoCôa André Tomás Santos / António Fernando Barbosa / Luís Luís / Marcelo Silvestre / Thierry Aubry

537 Imagens fantasmagóricas, silhuetas elusivas: as figuras humanas na arte do Paleolítico Superior da região do Côa Mário Reis

$55^{1}$ Os motivos zoomórficos representados nas placas de tear de Vila Nova de São Pedro (Azambuja, Portugal) Andrea Martins / César Neves / José M. Arnaud / Mariana Diniz

571 Arte Rupestre do Monte de Góios (Lanhelas, Caminha). Síntese dos resultados dos trabalhos efectuados em 2007-2009 Mário Varela Gomes

599 Gravuras rupestres de barquiformes no Monte de S. Romão, Guimarães, Noroeste de Portugal Daniela Cardoso

613 Círculos segmentados gravados na Bacia do Rio Lima (Noroeste de Portugal): contributos para o seu estudo Diogo Marinho / Ana M.S. Bettencourt / Hugo Aluai Sampaio

631 Equídeos gravados no curso inferior do Rio Mouro, Monção (NW Portugal). Análise preliminar Coutinho, L.M. / Bettencourt, A.M.S / Sampaio, Hugo A.S

645 Paletas na Arte Rupestre do Noroeste de Portugal. Inventário preliminar Bruna Sousa Afonso / Ana M. S. Bettencourt / Hugo A. Sampaio 


\section{Pré-História}

661 O projeto Miño/Minho: balanço de quatro anos de trabalhos arqueológicos Sérgio Monteiro-Rodrigues / João Pedro Cunha-Ribeiro / Eduardo Méndez-Quintas / Carlos Ferreira / Pedro Xavier / José Meireles / Alberto Gomes / Manuel Santonja / Alfredo Pérez-González

677 A ocupação paleolítica da margem esquerda do Baixo Minho: a indústria lítica do sítio de Pedreiras 2 (Monção, Portugal) e a sua integração no contexto regional Carlos Ferreira / João Pedro Cunha-Ribeiro / Sérgio Monteiro-Rodrigues / Eduardo Méndez-Quintas / Pedro Xavier / José Meireles / Alberto Gomes / Manuel Santonja / Alfredo Pérez-González

693 O sítio acheulense do Plistocénico médio da Gruta da Aroeira Joan Daura / Montserrat Sanz / Filipa Rodrigues / Pedro Souto / João Zilhão

703 As sociedades neandertais no Barlavento algarvio: modelos preditivos com recurso aos SIG

Daniela Maio

715 A utilização de quartzo durante o Paleolítico Superior no território dos vales dos rios Vouga e Côa

Cristina Gameiro / Thierry Aubry / Bárbara Costa / Sérgio Gomes / Luís Luís / Carmen Manzano / André Tomás Santos

733 Uma perspetiva diacrónica da ocupação do concheiro do Cabeço da Amoreira (Muge, Portugal) a partir da tecnologia lítica Joana Belmiro / João Cascalheira / Célia Gonçalves

745 Novos dados sobre a Pré-história Antiga no concelho de Palmela. A intervenção arqueológica no sítio do Poceirão I

Michelle Teixeira Santos

757 Problemas em torno de Datas Absolutas Pré-Históricas no Norte do Alentejo Jorge de Oliveira

771 Povoamento pré-histórico nas áreas montanhosas do NO de Portugal: o Abrigo 1 de Vale de Cerdeira Pedro Xavier / José Meireles / Carlos Alves

783 Apreciação do povoamento do Neolítico Inicial na Baixa Bacia do Douro. A Lavra I (Serra da Aboboreira) como caso de estudo Maria de Jesus Sanches

797 O Processo de Neolitização na Plataforma do Mondego: os dados do Sector C do Outeiro dos Castelos de Beijós (Carregal do Sal)

João Carlos de Senna-Martinez / José Manuel Quintã Ventura / Andreia Carvalho / Cíntia Maurício

823 Novos trabalhos na Lapa da Bugalheira (Almonda, Torres Novas) Filipa Rodrigues / Pedro Souto / Artur Ferreira / Alexandre Varanda / Luís Gomes / Helena Gomes / João Zilhão

837 A pedra polida e afeiçoada do sítio do Neolítico médio da Moita do Ourives (Benavente, Portugal)

César Neves

857 Casal do Outeiro (Encarnação, Mafra): novos contributos para o conhecimento do povoamento do Neolítico final na Península de Lisboa.

Cátia Delicado / Carlos Maneira e Costa / Marta Miranda / Ana Catarina Sousa

873 Stresse infantil, morbilidade e mortalidade no sítio arqueológico do Neolítico Final/ Calcolítico ( $4^{\circ}$ e $3^{\circ}$ milénio a.C.) do Monte do Carrascal 2 (Ferreira do Alentejo, Beja) Liliana Matias de Carvalho / Sofia N. Wasterlain 
885 Come together: O Conjunto Megalítico das Motas (Monção, Viana do Castelo) e as expressões Campaniformes do Alto Minho Ana Catarina Basílio / Rui Ramos

899 Trabalhos arqueológicos no sítio Calcolítico da Pedreira do Poio Carla Magalhães / João Muralha / Mário Reis / António Batarda Fernandes

913 O sítio arqueológico de Castanheiro do Vento. Da arquitectura do sítio à arquitectura de um território João Muralha Cardoso

925 Estudo zooarqueológico das faunas do Calcolítico final de Vila Nova de São Pedro (Azambuja, Portugal): Campanhas de 2017 e 2018 Cleia Detry / Ana Catarina Francisco / Mariana Diniz / Andrea Martins / César Neves / José Morais Arnaud

943 As faunas depositadas no Museu Arqueológico do Carmo provenientes de Vila Nova de São Pedro (Azambuja): as campanhas de 1937 a 1967 Ana Catarina Francisco / Cleia Detry / César Neves / Andrea Martins / Mariana Diniz / José Morais Arnaud

959 Análise funcional de material lítico em sílex do castro de Vila Nova de S. Pedro (Azambuja, Portugal): uma primeira abordagem Rafael Lima

971 O recinto da Folha do Ouro 1 (Serpa) no contexto dos recintos de fossos calcolíticos alentejanos

António Carlos Valera / Tiago do Pereiro / Pedro Valério / António M. Monge Soares

\section{Proto-História}

987 Produção de sal marinho na Idade do Bronze do noroeste Português. Alguns dados para uma reflexão

Ana M. S. Bettencourt / Sara Luz / Nuno Oliveira / Pedro P. Simões / Maria Isabel C. Alves / Emílio Abad-Vidal

1001 A estátua-menir do Pedrão ou de São Bartolomeu do Mar (Esposende, noroeste de Portugal) no contexto arqueológico da fachada costeira de entre os rios Neiva e Cávado Ana M. S. Bettencourt / Manuel Santos-Estévez / Pedro Pimenta Simões / Luís Gonçalves

1015 O Castro do Muro (Vandoma/Baltar, Paredes) - notas para uma biografia de ocupação da Idade do Bronze à Idade Média

Maria Antónia D. Silva / Ana M. S. Bettencourt / António Manuel S. P. Silva / Natália Félix

1031 Do Bronze Final à Idade Média - continuidades e hiatos na ocupação de Povoados em Oliveira de Azeméis João Tiago Tavares / Adriaan de Man

1041 As faunas do final da Idade do Bronze no Sul de Portugal: leituras desde o Outeiro do Circo (Beja)

Nelson J. Almeida / Íris Dias / Cleia Detry / Eduardo Porfírio / Miguel Serra

1055 A Espada do Monte das Oliveiras (Serpa) - uma arma do Bronze Pleno do Sudoeste Rui M. G. Monge Soares / Pedro Valério / Mariana Nabais / António M. Monge Soares

1065 São Julião da Branca (Albergaria-a-Velha) - Investigação e valorização de um povoado do Bronze Final

António Manuel S. P. Silva / Paulo A. P. Lemos / Sara Almeida e Silva / Edite Martins de Sá

1083 Do castro de S. João ao Mosteiro de Santa Clara: notícia de uma intervenção arqueológica, em Vila do Conde Rui Pinheiro 
1095 O castro de Ovil (Espinho), um quarto de século de investigação - resultados e questões em aberto

Jorge Fernando Salvador / António Manuel S. P. Silva

1111 O Castro de Salreu (Estarreja), um povoado proto-histórico no litoral do Entre Douro e Vouga

Sara Almeida e Silva / António Manuel S. P. Silva / Paulo A. P. Lemos / Edite Martins de Sá

1127 Castro de Nossa Senhora das Necessidades (Sernancelhe): uma primeira análise artefactual Telma Susana O. Ribeiro

${ }_{1141}$ A cividade de Bagunte. O estado atual da investigação Pedro Brochado de Almeida

1153 Zoomorfos na cerâmica da Idade do Ferro no NW Peninsular: inventário, cronologias e significado Nuno Oliveira / Cristina Seoane

1163 Vasos gregos em Portugal: diferentes maneiras de contar a história do intercâmbio cultural na Idade do Ferro

Daniela Ferreira

1175 Os exotica da necrópole da Idade do Ferro do Olival do Senhor dos Mártires (Alcácer do Sal) no seu contexto regional

Francisco B. Gomes

\section{Antiguidade Clássica e Tardia}

1191 O uso de madeira como combustível no sítio da Quinta de Crestelos (Baixo Sabor): da Idade do Ferro à Romanização Filipe Vaz / João Tereso / Sérgio Simões Pereira / José Sastre / Javier Larrazabal Galarza / Susana Cosme / José António Pereira / Israel Espi

1207 Cultivos de Época Romana no Baixo Sabor: continuidade em tempos de mudança? João Pedro Tereso / Sérgio Simões Pereira / Filipe Santos / Luís Seabra / Filipe Vaz

1221 A casa romana na Hispânia: aplicação dos modelos itálicos nas províncias ibéricas Fernanda Magalhães / Diego Machado / Manuela Martins

1235 As pinturas murais romanas da Rua General Sousa Machado, n. ${ }^{5}$ 1, Chaves José Carvalho

1243 Trás do Castelo (Vale de Mir, Pegarinhos, Alijó) - Uma exploração agrícola romana do Douro

Tony Silvino / Pedro Pereira

1255 A sequência de ocupação no quadrante sudeste de Bracara Augusta: as transformações de uma unidade doméstica Lara Fernandes / Manuela Martins

1263 Os Mosaicos com decoração geométrica e geométrico-vegetalista dos sítios arqueológicos da área do Conuentus Bracaraugustanus. Novas abordagens quanto à conservação, restauro, decoração e datação Maria de Fátima Abraços / Licínia Wrench

1277 “Casa Romana” do Castro de São Domingos (Cristelos, Lousada): Escavação, Estudo e Musealização Paulo André de P. Lemos

1291 A arqueobotânica no Castro de Guifões (Matosinhos, Noroeste de Portugal): O primeiro estudo carpológico

Luís Seabra / Andreia Arezes / Catarina Magalhães / José Varela / João Pedro Tereso 
1305 Um Horreum Augustano na Foz do Douro (Monte do Castelo de Gaia, Vila Nova de Gaia) Rui Ramos

1311 Ponderais romanos na Lusitânia: padrões, formas, materiais e contextos de utilização Diego Barrios Rodríguez

1323 Um almofariz centro-itálico na foz do Mondego

Marco Penajoia

1335 Estruturas romanas de Carnide - Lisboa Luísa Batalha / Mário Monteiro / Guilherme Cardoso

1347 O contexto funerário do sector da "necrópole NO" da Rua das Portas de S. Antão (Lisboa): o espaço, os artefactos, os indivíduos e a sua interconectividade na interpretação do passado Sílvia Loja, José Carlos Quaresma, Nelson Cabaço, Marina Lourenço, Sílvia Casimiro, Rodrigo Banha da Silva, Francisca Alves-Cardoso

${ }_{1361}$ Povoamento em época Romana na Amadora - resultados de um projeto pluridisciplinar Gisela Encarnação / Vanessa Dias

1371 A Arquitectura Residencial em Mirobriga (Santiago do Cacém): contributo a partir de um estudo de caso Filipe Sousa / Catarina Felício

${ }_{1385}$ O fim do ciclo. Saneamento e gestão de resíduos nos edifícios termais de Mirobriga (Santiago do Cacém)

Catarina Felício / Filipe Sousa

1399 Balsa, Topografia e Urbanismo de uma Cidade Portuária Vítor Silva Dias / João Pedro Bernardes / Celso Candeias / Cristina Tété Garcia

1413 No Largo das Mouras Velhas em Faro (2017): novas evidências da necrópole norte de Ossonoba e da sua ocupação medieval Ricardo Costeira da Silva / Paulo Botelho / Fernando Santos / Liliana Nunes

1429 Instrumentos de pesca recuperados numa fábrica de salga em Ossonoba (Faro) Inês Rasteiro / Ricardo Costeira da Silva / Paulo Botelho

1439 A Necrópole Romana do Eirô, Duas Igrejas (Penafiel): intervenção arqueológica de 2016 Laura Sousa / Teresa Soeiro

1457 Ritual, descarte ou afetividade? A presença de Canis lupus familiaris na Necrópole Noroeste de Olisipo (Lisboa)

Beatriz Calapez Santos / Sofia Simões Pereira / Rodrigo Banha da Silva / Sílvia Casimiro / Cleia Detry / Francisca Alves Cardoso

1467 Dinâmicas económicas em Bracara na Antiguidade Tardia Diego Machado / Manuela Martins / Fernanda Magalhães / Natália Botica

1479 Cerâmicas e Vidros da Antiguidade Tardia do Edifício sob a Igreja do Bom Jesus (Vila Nova de Gaia) Joaquim Filipe Ramos

1493 Novos contributos para a topografia histórica de Mértola no período romano e na Antiguidade Tardia Virgílio Lopes

\section{8. Época Medieval}

1511 Cerâmicas islâmicas no Garb setentrional "português": algumas evidências e incógnitas Constança dos Santos / Helena Catarino / Susana Gómez / Maria José Gonçalves / Isabel Inácio / Gonçalo Lopes / Jacinta Bugalhão / Sandra Cavaco / Jaquelina Covaneiro / Isabel Cristina Fernandes / Ana Sofia Gomes 
1525 Contributo para o conhecimento da cosmética islâmica, em Silves, durante a Idade Média Rosa Varela Gomes

1537 Yábura e o seu território - uma análise histórico-arqueológica de Évora entre os séculos VIII-XII José Rui Santos

1547 A encosta sul do Castelo de Palmela - resultados preliminares da escavação arqueológica Luís Filipe Pereira / Michelle Teixeira Santos

1559 A igreja de São Lourenço (Mouraria, Lisboa): um conjunto de silos e de cerâmica medieval islâmica

Andreia Filipa Moreira Rodrigues

1571 O registo material de movimentações populacionais no Médio Tejo, durante os séculos XII-XIII. Dois casos de "sunken featured buildings", nos concelhos de Cartaxo e Torres Novas Marco Liberato / Helena Santos / Nuno Santos

1585 O nordeste transmontano nos alvores da Idade média. Notas para reflexão Ana Maria da Costa Oliveira

1601 Sepulturas escavadas na rocha do Norte de Portugal e do Vale do Douro: primeiros resultados do Projecto SER-NPVD

Mário Jorge Barroca / César Guedes / Andreia Arezes / Ana Maria Oliveira

1619 "Portucalem Castrum Novum" entre o Mediterrâneo e o Atlântico: o estudo dos materiais cerâmicos alto-medievais do arqueossítio da rua de D. Hugo, nํ. 5 (Porto) João Luís Veloso

1627 A Alta Idade Média na fronteira de Lafões: notas preliminares sobre a Arqueologia no Concelho de Vouzela

Manuel Luís Real / Catarina Tente

1641 Um conjunto cerâmico medieval fora de portas: um breve testemunho aveirense Susana Temudo

${ }_{1651}$ Os Lóios do Porto: uma perspetiva integrada no panorama funerário da Baixa Idade Média à Época Moderna em meios urbanos em Portugal

Ana Lema Seabra

1659 O Caminho Português Interior de Santiago como eixo viário na Idade Média Pedro Azevedo

1665 Morfologia Urbana: Um exercício em torno do Castelo de Ourém André Donas-Botto / Jaqueline Pereira

1677 Intervenção arqueológica na Rua Marquês de Pombal/Largo do Espírito Santo (Bucelas, Loures)

Florbela Estêvão / Nathalie Antunes-Ferreira / Dário Ramos Neves / Inês Lisboa

1691 O Cemitério Medieval do Poço do Borratém e a espacialidade funerária na cidade de Lisboa Inês Belém / Vanessa Filipe / Vasco Noronha Vieira / Sónia Ferro / Rodrigo Banha da Silva

1705 Um Espaço Funerário Conventual do séc. XV em Lisboa: o caso do Convento de São Domingos da Cidade Sérgio Pedroso / Sílvia Casimiro / Rodrigo Banha da Silva / Francisca Alves Cardoso

\section{9. Época Moderna e Contemporânea}

1721 Arqueologia Moderna em Portugal: algumas reflexões críticas em torno da quantificação de conjuntos cerâmicos e suas inferências históricas e antropológicas Rodrigo Banha da Silva / André Bargão / Sara da Cruz Ferreira

1733 Faianças de dois contextos entre os finais do século XVI e XVIII do Palácio dos Condes de Penafiel, Lisboa

Martim Lopes / Tomás Mesquita 
1747 Um perfil de consumo do século XVIII na foz do Tejo: O caso do Mercado da Ribeira, Lisboa Sara da Cruz Ferreira / Rodrigo Banha da Silva / André Bargão

1761 Os Cachimbos dos Séculos XVII e XVIII do Palácio Mesquitela e Convento dos Inglesinhos (Lisboa)

Inês Simão / Marina Pinto / João Pimenta / Sara da Cruz Ferreira / André Bargão / Rodrigo Banha da Silva

1775 "Tomar os fumos da erua que chamão em Portugal erua sancta». Estudo de Cachimbos provenientes da Rua do Terreiro do Trigo, Lisboa

Miguel Martins de Sousa / José Pedro Henriques / Vanessa Galiza Filipe

1787 Cachimbos de Barro Caulínitico da Sé da Cidade Velha (República de Cabo Verde)

Rodrigo Banha da Silva / João Pimenta / Clementino Amaro

1801 Algumas considerações sobre espólio não cerâmico recuperado no Largo de Jesus (Lisboa) Carlos Boavida

1815 Adereços de vidro, dos séculos XVI-XVIII, procedentes do antigo Convento de Santana de Lisboa (anéis, braceletes e contas)

Joana Gonçalves / Rosa Varela Gomes / Mário Varela Gomes

1837 Da ostentação, luxo e poder à simplicidade do uso quotidiano: arqueologia e simbologia de joias e adornos da Idade Moderna Portuguesa Jéssica Iglésias

1849 Os amuletos em Portugal - dos objetos às superstições: o coral vermelho Alexandra Vieira

1865 Cerâmicas de Vila Franca de Xira nos séculos XV e XVI Eva Pires

1879 «Não passa por teu o que me pertence». Marcas de individualização associadas a faianças do Convento de Nossa Senhora de Aracoeli, Alcácer do Sal Catarina Parreira / Íris Fragoso / Miguel Martins de Sousa

1891 Cerâmica de Leiria: alguns focos de produção

Jaqueline Pereira / André Donas-Botto

1901 Os Fornos na Rua da Biquinha, em Óbidos Hugo Silva / Filipe Oliveira

1909 A casa de Pêro Fernandes, contador dos contos de D. Manuel I: o sítio arqueológico da Silha do Alferes, Seixal (século XVI) Mariana Nunes Ferreira

1921 O Alto da Vigia (Sintra) e a vigilância e defesa da costa Alexandre Gonçalves / Sandra Santos

1937 O contexto da torre sineira da Igreja de Santa Maria de Loures Paulo Calaveira / Martim Lopes

1949 A Necrópole do Hospital Militar do Castelo de São Jorge e as práticas funerárias na Lisboa de Época Moderna Susana Henriques / Liliana Matias de Carvalho / Ana Amarante / Sofia N. Wasterlain

1963 SAND - Sarilhos Grandes Entre dois Mundos: o adro da Igreja e a Paleobiologia dos ossos humanos recuperados

Paula Alves Pereira / Roger Lee Jesus / Bruno M. Magalhães

1975 Expansão urbana da vila de Cascais no século XVII e XVIII: a intervenção arqueológica na Rua da Vitória no 15 a 17

Tiago Pereira / Vanessa Filipe

1987 Novos dados para o conhecimento do Urbanismo de Faro em época Moderna Ana Rosa 
1995 Um exemplo de Arqueologia Urbana em Alcoutim: o Antigo Edifício dos CTT Marco Fernandes / Marta Dias / Alexandra Gradim / Virgílio Lopes / Susana Gómez Martínez

2007 Palácio dos Ferrazes (Rua das Flores/Rua da Vitória, Porto): a cocheira de Domingos Oliveira Maia

Francisco Raimundo

2021 As muitas vidas de um edifício urbano: História, Arqueologia e Antropologia no antigo Recreatório Paroquial de Penafiel Helena Bernardo / Jorge Sampaio / Marta Borges

2035 O convento de Nossa Senhora da Esperança de Ponta Delgada: o contributo da arqueologia para o conhecimento de um monumento identitário João Gonçalves Araújo / N’Zinga Oliveira

2047 Arqueologia na ilha do Corvo... em busca da capela de Nossa Senhora do Rosário Tânia Manuel Casimiro / José Luís Neto / Luís Borges / Pedro Parreira

2059 Perdidos à vista da Costa. Trabalhos arqueológicos subaquáticos na Barra do Tejo Jorge Freire / José Bettencourt / Augusto Salgado

2071 Arqueologia marítima em Cabo Verde: enquadramento e primeiros resultados do projecto CONCHA

José Bettencourt / Adilson Dias / Carlos Lima / Christelle Chouzenoux / Cristóvão Fonseca / Dúnia Pereira / Gonçalo Lopes / Inês Coelho / Jaylson Monteiro / José Lima / Maria Eugénia Alves / Patrícia Carvalho / Tiago Silva

2085 Trabalhos arqueológicos na Cidade Velha (Ribeira Grande de Santiago, Cabo Verde): reflexões sobre um projecto de investigação e divulgação patrimonial André Teixeira / Jaylson Monteiro / Mariana Mateus / Nireide Tavares / Cristovão Fonseca / Gonçalo C. Lopes / Joana Bento Torres / Dúnia Pereira / André Bargão / Aurélie Mayer / Bruno Zélie / Carlos Lima / Christelle Chouzenoux / Inês Henriques / Inês Pinto Coelho / José Lima / Patrícia Carvalho / Tiago Silva

2103 A antiga fortificação de Quelba / Khor Kalba (E.A.U.). Resultados de quatro campanhas de escavações, problemáticas e perspectivas futuras Rui Carita / Rosa Varela Gomes / Mário Varela Gomes / Kamyar Kamyad

2123 Colónias para homens novos: arqueologia da colonização agrária fascista no noroeste ibérico Xurxo Ayán Vila / José Mạ . Señorán Martín 


\title{
APRECIAÇÃO DO POVOAMENTO DO NEOLITICO INICIAL NA BAIXA BACIA DO DOURO. A LAVRA I (SERRA DA ABOBOREIRA) COMO CASO DE ESTUDO
}

\author{
Maria de Jesus Sanches ${ }^{1}$
}

\begin{abstract}
RESUMO
Este texto dedica-se à discussão da documentação arqueográfica do habitat do Neolitico inicial de Lavra I (Serra da Aboboreira), incidindo: nos fenómenos de sedimentação e formação do registo arqueológico; na definição do tipo de ocupação; no esclarecimento das datas de C14. Debate ainda o modo como a Lavra I se inscreve no início do processo de neolitização do Norte de Portugal e Baixa bacia do Douro, destacando, na Serra da Aboboreira a possibilidade temporal e espacial de se poder correlacionar com as mamoas mais antigas, no $2^{\circ}$ quartel do $5^{\circ}$ mil.a.C.
\end{abstract}

Palavras-chave: Bacia do Baixo Douro, Neolítico inicial, Tumulus, Decoração em boquique.

\begin{abstract}
This text is devoted to the discussion of the archaeographic documentation of the Early Neolithic archaeological site of Lavra I (Serra da Aboboreira; Aboboreira Mountain), bringing into focus the phenomena of sedimentation and formation of the archaeological record, the type of occupation and the explanation of the $\mathrm{Cr}_{4}$ dates. It also discusses how Lavra I is inscribed at the beginning of the neolithicization process in the North of Portugal and the Lower Douro basin, highlighting, in Serra da Aboboreira, the possibility of a temporal and spatial relationship with the oldest barrows (mamoas), in the $2^{\text {nd }}$ quarter of the $5^{\text {th }}$ mil. B.C.
\end{abstract}

Keywords: Lower Douro Basin, Early Neolithic, Tumuli/barrows, Boquique decoration.

\section{PREÂMBULO}

Começamos por esclarecer que neste artigo denominaremos o sítio da Lavra I somente como sítio, deixando para a exposição e discussão a sua natureza. Por seu turno, na ocupação pré-histórica mais recente - Lavra II - datada do séc. VIII a.C., já o entendemos como um povoado com estruturas habitacionais em negativo.

Contou este sítio com diversas publicações parcelares e referências diversas, sobretudo no âmbito do Neolitico Inicial (Sanches, 2003 e bibliografia aí citada). Mencione-se, todavia, a Monografia da Lavra, que constituiu a Dissertação de Mestrado de Cátia Mendes (Mendes, 2017) - tendo como base documental as escavações por mim desenvolvidas nos anos de 1982, 83, 84 e 88 -, e que aguarda publi- cação. Esta obra, além de toda a informação gráfica recolhida na escavação, contem ainda os resultados das diversas análises e, bem assim, a descrição de todo o material arqueológico, com ênfase para o lítico. Porque vocacionada para o estudo da ocupação do B. Final, tornava-se urgente a interpretação da ocupação mais antiga. Ou seja, (i) que caraterizasse a Lavra I à escala do sítio - com incidência nos ecossistemas antigos, nos fenómenos de sedimentação e formação do registo arqueológico e na definição da ocupação em presença; (ii) que esclarecesse a coerência das datas de $\mathrm{C}_{14}$ das estruturas de combustão, neolíticas, aparecendo por vezes referenciadas na bibliografia arqueológica como tendo contextos pouco claros; e ainda que (iii) indicasse de que modo a Lavra se inscreve no início do longo período de neolitização do Norte de Portugal e Baixa Bacia do

1. CITCEM-FLUP; mjsanches77@gmail.com 
Douro, onde ocupa temporalmente não somente o período que precede a construção de mamoas, mas outrossim que pode ser contemporâneo daquelas mais antigas da Aboboreira, uma ideia já avançada há quase duas décadas por Domingos Cruz (2001, I, p.303; Sanches, 2021, no prelo). No que respeita a este último ponto, devido ao relativamente reduzido espaço aqui concedido em termos editoriais, remetemos tanto aspetos do texto, como bibliografia ou figuras, para um outro que se encontra em publicação (Sanches 2021, no prelo); nos dois primeiros para a supracitada Dissertação (Mendes, 2017).

\section{LAVRA I. INTEGRAÇÃO BIOGEOGRÁFICA NO PRESENTE E NO PASSADO}

Lavra I situa-se numa das plataformas SW da Serra da Aboboreira-41,154661N; -8,07708W - rondado a sua alt. $640 \mathrm{~m}$. Embora localizada numa das cordas das montanhas sublitorais do NW da P. Ibérica (Aboboreira-Marão-Alvão-maciço galaico duriense), onde o pano de fundo é o clima temperado frio, de influência marítima da zona biogeográfica atlântica, vai ocupar o patamar intermédio, de transição - Terra de Transição (40o-6oo/70o m). Assim, em termos geográficos, climáticos e topográficos, Lavra I integra-se, singularmente, em local privilegiado entre os ecossistemas da zona temperada fria de mon$\operatorname{tanha}(600 / 700$ a 90o/100o m) e aqueles da zona claramente temperada (abaixo dos $400 \mathrm{~m}$ ). Cumulativamente, este patamar permite não somente $o$ acesso relativamente rápido à Serra, mas ainda aos vales dos ribeiros que configuram a bacia hidrográfica do Tâmega (a SW) e do Ovil-Douro, a SE e Sul, pois que é aqui que, sob a forma de lameiros se começam a originar tais bacias (Figura 1 ).

Similar situação fisiográfica tem o sítio da Mamoa da Lavra, situado a c. de $200 \mathrm{~m}$ a SSW de Lavra I, cujo solo antigo enterrado sob a mamoa com diversos vestígios arqueológicos (cerâmicas manuais lisas e moinho), configurando o que terá restado de um habitat similar a Lavra I na sua estratégia de implantação em termos socioecónomicos².

Assumindo desde já que a Lavra foi ocupada, como mínimo, entre 4900/480o cal BC, (ver 3.), adiantamos que não existem dados paleobotânicos completos na Serra da Aboboreira especifica e particular-

2. Informação de Domingos Cruz e Relatório de escavação inédito, que agradecemos. mente para o $6^{\circ}, 5^{\circ}$ e mesmo $4^{\circ}$ mil. a.C.. Porém, da conjugação dos vários resultados ali obtidos é-nos permitido concluir o seguinte. No solo enterrado sob a Mamoa 1 de Chã de Carvalhal (a c. de 1k a SSW da Lavra) - cam. 3 - que se terá formado em pleno Ótimo Climático Atlântico, entre c. de 6120/5640 e 406o/4045 cal BC (Cruz 1992, p.28 e 6o), a antracologia enfatiza a importância da vegetação arbórea relativamente ao estrato herbáceo, ou seja, a expansão do carvalhal misto (Quercetum mixtum), com domínio para aquele de folha caduca, e a ausência de Pinus, tornando-o assim característico do clima temperado atlântico (Cruz, 1992, p. 64). Tal informação ganha importância se comparada com aquela, embora pontual, doutros solos enterrados ou prévios à construção dos monumentos megalíticos (datados de entre os meados do $6^{\circ}$ e os finais do $5^{\circ}$ mil. a.C.) e situados em todos os patamares altimétricos, onde se regista também uma relativa importância da vegetação arbórea (além, evidentemente, da herbácea). Algumas pastagens (estrato herbáceo não relacionável com práticas agrícolas, dedutível do estudo carpológico) são já referidas para o solo enterrado da Mamoa do Monte Maninho, a 1,4 Km a Sudoeste da Lavra I e situada no mesmo patamar altimétrico $615 \mathrm{~m}$ - e que tem uma cronologia coincidente com a que propomos aqui para a Lavra (Cruz, 1988, p. 79 e 83; 2001, p. 303). Em períodos posteriores - a partir aprox. de 4300 a.C. -, nota-se uma significativa alteração nos ecossistemas, sobretudo na vizinha Mamoa 1 de Chã de Carvalhal, que exibe um considerável estrato herbáceo e arbustivo, indicando paisagem mais aberta, mas paralela a uma maior riqueza/diversidade arbórea: pinheiro, salgueiro, bétula, carvalho caducifólio (Cruz, 1992, p. 64). Há então a reter que as atuais diferenças florísticas entre os diferentes patamares da Aboboreira não seriam tão marcadas durante o Ótimo Climático Atlântico, periodo em que se inscreve Lavra I, em que algumas matas de carvalhais teriam subido mais em altitude, onde ocupariam nichos abrigados. Todavia, e atendendo à natureza dos dados aqui manipulados, devemos ser cautelosos quanto à proporção relativa da vegetação arbórea da Serra. Nas montanhas sublitorais a palinologia reporta que o patamar meso climático de 60o-70o m, após o evento climático/fenómeno erosivo GH-8.2, vai mostrar a expansão da floresta temperada contínua, sendo que acima dessa cota se tornaram mais acantonados os bosques e mais expressivas os matagais, as charnecas e as pastagens de 
gramíneas (Ramil Rego et al., 2010). Tais dados condizem também com o resultado polínico das turfeiras do Alto Paiva - vizinha Serra do Montemuro, a sul do Douro, (eg. Chã das Lameiras: Sáez, Figueiral \& Cruz, 2012), de modo que os ecossistemas da Lavra no início do $5^{\circ}$ mil a.C. - na qual a recolha pontual na E. Combustão 4 mostra domínio quase absoluto de Quercus de folha caduca, mas também de medronheiro e pilriteiro/espinheiro alvar (Mendes, 2017, p. 214) - evidenciariam uma floresta de clima marcadamente atlântico, mas de caraterísticas locais temperadas, ou seja, anunciam ecossistemas mesófilos, com algumas pastagens cuja riqueza relativa devemos, no seu conjunto, desde logo relevar.

\section{LAVRA I. ESTRATIGRAFIA E ESTRUTURAS HABITACIONAIS}

A estratigrafia do sítio se vista no seu conjunto, quer dizer, em articulação com a atual topografa do local (Figura 2) e desenho, também topográfico, do bed-rock (saibro) - elucidado pelos diferentes cortes transversais e longitudinais (Mendes, 2017, Figs. III, VI e VII) (Figura 3) e natureza dos estratos, permite identificar os principais fenómenos de estratificação. Configurando a cabeceira aplanada de formação de uma linha de agua que se vai manifestar a Oeste (a cotas inferiores: 63om), logo o bed-rock apresenta duas leves pendentes complementares - uma E-W (dominante) e outra S-N -, que definem uma bacia de deposição sedimentar onde se formou a camada 4. Esta tem todas as caracteristicas de um paleossolosolo espesso, embora granítico, compacto, castanho escuro com veios negros e de aspeto por vezes "gorduroso", que indicia a presença de matéria orgânica na sua formação sedimentar e pedológica. Embora sem datas absolutas, este solo poder-se-ia ter formado quer durante o aquecimento climático do Tardiglaciar, quer em fase posterior, durante o início do Holocénico, podendo estar ainda em formação/erosão aquando da ocupação humana do sítio da Lavra, se o compararmos com o supracitado solo enterrado sob a vizinha Chã de Carvalhal 1. Tem diferentes espessuras, mas estaria por certo erodido/decapitado nas cotas mais altas da zona oriental onde se abrem as estruturas datadas do Neolítico Inicial, mas ter-se-ia conservado, quase sem diferença sedimentar se comparado com a cam. 3 - que contém materiais neolíticos -, na parte média e ocidental desta área. A camada 3 é em muitos locais simplesmente o topo da camada 4, definindo-se noutros por conter sedimentos menos compactados e homogéneos que os da cam. 4. A camada 3, tal como a definimos em termos sedimentares, nunca foi detetada sobre o saibro. Porém, como se sabe, fenómenos de lixiviação em solos já pouco espessos e aflorantes - como teria acontecido sobre as Estruturas de combustão EC2 e EC 3 -, por um lado, e ocupações posteriores, da I do Bronze Final, poderão ter sido responsáveis por esse facto (Figura 2, 3, 4). Com efeito, durante aprox. 3 milénios - do $5^{\circ}$ aos inícios do $1^{\circ}$ mil. a.C. - ocorreram fenómenos climáticos-erosivos diversos - de novo atestados na M. de Chã de Carvalhal 1, sobretudo entre os inícios do $4^{\circ}$ e os finais do $3^{\circ}$ mil. a.C. (Cruz, 1992, p. 28 e 6o) -, o que, a par de eventuais usos agro-pastoris daquela área, terá provocado na Lavra lixiviação e deslocação sedimentar de baixa energia (na estratigrafia não existem vestígios de níveis de calhaus ou areias). Deste modo, no séc. $8^{\circ}$ a.C. (Mendes, 2017), o povoado da I do Bronze pode ter assentado, nas áreas mais orientais, num "solo humoso" relativamente fino porque "decapitado", resiliente, que subsistiria sobre as EC2 e EC3 (Figura 4-A), mas que não foi identificado como tal em termos sedimentares aquando da sua escavação arqueológica. Continha, mesmo assim, a maioria dos materiais arqueológicos da ocupação mais antiga, ou seja, instrumentos e restos de talhe característicos do Neolítico e ausentes dos conjuntos artefactuais do Bronze Final. Nas áreas central e sul, onde existem as cam. 4 e 3 - esta com algumas cerâmicas decoradas e materiais líticos -, algumas estruturas - como fossa $\mathrm{F} 1$ e a lareira L1 embora tendo datas antigas não podem ser associadas a esta ocupação. A ocupação do B. Final, patente na camada 2, esteve, também ela sujeita a ablações, deslocamentos e redeposições muito similares às mais antigas de modo que, quanto mais se caminha para ocidente, mais subcamadas sedimentares se registam. Todavia, seja pela deslocação antiga de sedimentos/decapitação (similar à que se verificou em Chã de Carvalhal I (Cruz, 1992, p. 28,6o), seja pelo caráter pouco marcante da ocupação neolítica na zona ocidental, a área do sítio neolítico é bem mais reduzida do que a do B. Final.

Com efeito, as estruturas neolíticas parecem concentrar-se na área aplanada, imediata ao pequeno "cabeço" (cota aprox. de $640 \mathrm{~m}$ ), do que resulta que terão sido maioritariamente destruídas pela abertura da estrada a qual cortou mesmo uma grande estrutura de combustão-EC1. As restantes três Es- 
truturas de Combustão alinham-se igualmente pelo traçado da estrada, a reduzidíssima distância desta (Figura 3) (Mendes, 2017, Fig. V). Apesar de na altura da escavação não se relacionarem com uma camada sedimentar discreta, que só poderia ter sido a cam. 3 (ver comentários precedentes), estariam ainda parcialmente cobertas de sedimentos durante o B. Final, de modo que em duas destas estruturas se conservou a $2^{\underline{a}}$ utilização acima do bordo, definido pelo saibro (Figura 4-B).

São, com efeito, muito similares entre si, tanto na sua forma como no modelo de uso e/ou condenação, pelo que são reveladoras do padrão habitacional e de organização comunitária em torno do fogo. São círculos quase perfeitos, com grande diâmetro - de 1,70 (na EC3) a 2,20 m (na EC2) -, cavadas no saibro a profundidades que variam entre 25 a $30 \mathrm{~cm}$, definindo-se como depressões regulares, de paredes algo convergentes, mas regulares e com fundo aplanado. Em dois casos ( $\mathrm{EC}_{3}$ e 4 ) este fundo está pejado de pequenos orifícios, similares a buracos de poste. De igual modo, o seu enchimento - e, por extensão, o modo de uso - é repetitivo: (i) a uma camada muito espessa de terra negra com muito carvão, por vezes de grande espessura ( 8 a $12 \mathrm{~cm}$ ) e algumas pedras pequenas, e que ocupa tanto o fundo como todo o perímetro interior, (ii) segue-se uma outra que, embora escura, não tem carvão e só ocupa a área central, formando um círculo quase perfeito cujo diâmetro varia entre $160 \mathrm{~cm}$ (na EC3) e $180-190 \mathrm{~cm}$ (na EC2) (Figura 4). Este enchimento atinge o bordo superior fossa e revela um modelo de uso em que a parte central, sem brasas, estaria reservada a fins culinários, permanecendo a substantiva parte periférica (variando entre 10 e $30 \mathrm{~cm}$ ) como calorímetro. Cumulativamente, as $\mathrm{EC}_{2}$ e $\mathrm{EC}_{3}$ registam uma segunda realização de fogo na sua parte central, que denominamos de Lareira 3 e 4, respetivamente. Embora com pequenas diferenças de pormenor, são lareiras formadas por empedrados de granito, alguns blocos de quartzito e terra com carvões. Em termos de organização espacial associam-se duas a duas (uma somente evidenciando a utilização "primeira" da fossa mais uma com uma segunda utilização), e a EC3 tem, complementarmente uma paliçada em arco e pelo menos quatro a sete buracos de poste, que também se lhe parecem associar (Mendes, 2017, Fig. IX) (Figura 3). Este último conjunto, a ser como o interpretamos, resguardaria a $\mathrm{EC}_{3}-\mathrm{L}_{4}$ dos ventos frios e húmidos de Norte e Noroeste, abrindo o es- paço a Oeste e Sudeste, onde passa a estrada. Mas é possivel que tal arco cavado no saibro também pudesse ter como finalidade a do resguardo da percolação das águas do solo.

Conjugando (i) a distribuição espacial destas estruturas na área ocidental da estrada, com (ii) a recuperação de quatro peças microlíticas do lado oriental da mesma- cujo saibro estaria, e está, a uma cota mais elevada ${ }^{3}$-, (iii) e com a distribuição espacial da cam. 3, calculamos que a área ocupada se aproximasse, por defeito, dos $500 \mathrm{~m} 2$, embora a concentração de estruturas habitacionais (incluindo a zona da estrada) incidisse numa área menor, que estimamos fosse em torno $300 \mathrm{~m} 2$.

\section{CRONOLOGIA}

As seis datas das três Estruturas de Combustão da Lavra I e das lareiras que se lhe sobrepõem já foram divulgadas e frequentemente citadas, e nesse ponto somente queremos fazer notar que embora tenham sido realizadas sobre carvões não particularmente selecionados (de vida curta), e de o Laboratório GAK apresentar grandes desvios padrão, foram submetidas a mais dois laboratórios (ICEN e UGRA) apresentando, no conjunto, resultados que nos parecem coerentes entre si, já que todas se recobrem estatisticamente no período de entre $5200-4800 \mathrm{cal}$ BC $(2 \sigma)$ (Mendes, 2017, Quadro 6 e Gráfico 21). Aceitando, por cautela, somente os resultados, sobrepostos, das 2 datas dos dois laboratórios com menor desvio padrão - que datam a base e a $2^{2}$ utilização da $E_{3}$ - o período de uso estaria entre 4900/480o e 4500 BC (datas calibradas a $2 \sigma$ ). Tal valor coincide genericamente com o intervalo da data UGRA-267, aquela que, de entre as duas, apresenta maior desvio padrão, como era expectável pois trata-se de distribuição estatística de valores. Todavia, o resultado de quaisquer dos três laboratórios não permite aferir se (e quais) as estruturas de combustão (EC1 a 4) e as lareiras (que se lhes sobrepõem em 2 casos - $\mathrm{L}_{3}$ e L4) seriam contemporâneas umas das outras, pelo que não sugerem sequer se se tratou aqui de uma ocu-

3. Segundo a lei da gravidade, estas peças, que jaziam sobre o saibro, estarão ali por motivos antrópicos. Buril diedro de ângulo e lasca cortical (D'6); lasca microlítica de dorso (E'6); lamela de sílex fragmentada (E'1 - Museu de Baião com no 209.98), jazendo encaixada numa reentrância do saibro junto de uma pequena estrutura de combustão vestigial -L2-, mas esta poderá pertencer a qualquer uma das ocupações. 
pação pontual (não repetida), se sazonal, (sujeita a retorno calendarizado ao mesmo lugar), se mesmo permanente. Com efeito, a amostra da $2^{\underline{a}}$ utilização da EC3 (L4) - ICEN-76-6o6o \pm 60 BP (5210-48o1 cal $\mathrm{BC} 2 \sigma$ ) - é, em termos de intervalo de probabilidades, aparentemente mais "antiga" que a da $1^{\mathrm{a}}$ utilização - UGRA-267: $5830 \pm 90$ BP (4900-4470 cal BC $2 \sigma)$. Nenhuma das restantes datas antigas deste sítio pode ser aceite como datando o contexto arqueológico a que se associam: a) como é o caso da Lareira 1 , já nomeada atrás; b) ou das fossas Fı e F’ı (esta última com datas muito díspares).

Tem sido por diversas vezes considerado que as datas de carvão - particularmente de grandes troncos como aqueles que se registavam na camada da base das quatro EC ( 2 a 4) - acusarão o efeito de lenha antiga. Não discordando desse raciocínio, reafirmamos a coerência dos resultados do conjunto; todavia, devemos então acrescentar que a queima de grossos troncos (por ex. de vetustos carvalhos, na EC2) indicarão um comportamento recorrente na Lavra I, que seria a da recolha de troncos já velhos ou parcialmente queimados (por incêndios naturais ou antrópicos), dado que não existe tecnologia para o abate de árvores de grandes dimensões.

\section{ALGUMAS NOTAS SOBRE OS MATERIAIS ARQUEOLÓGICOS E SUA DISTRIBUIÇÃO ESPACIAL}

O material lítico talhado, de caracter dominantemente microlítico, compreende 169 peças, respeitando a: a) núcleos $(7,6 \%)$ - informes, poliédricos e bipolares, sobretudo esgotados; b) material de debitagem $(30,18 \%)$ - sobretudo lascas, maioritariamente não corticais, com ou sem talão (por motivo de fratura), mas também três lamelas em sílex; c) material residual (29,59\%) - principalmente em quartzo (fragmentos amorfos); d) utensílios $(32,54 \%)$. Estes abarcam lascas retocadas, raspadores, raspadeiras, buris (e microburis), furadores (e microfuradores), denticulados e truncaturas, além de uma lamela retocada (em sílex) e pontas microlíticas. A matéria prima quase exclusiva é o quartzo, particularmente o quartzo leitoso de filão o que, acrescentando algumas peças de quartzo hialino e calcedónia, indica preferência pelo uso de recursos da região envolvente (material local ou regional). O sílex (quatro lamelas e um microburil) indiciaria relações com comunidades extrarregionais, e teria chegado já sob a forma de instrumentos talhados uma vez que não existem na estação vestígios do seu talhe. (Mendes, 2017, p. 33-50 e Anexo 3). Cabe aqui referir uma pequena peça faceada por fricção, de corneana, e com vestígios de corante castanho. O material lítico referido, conquanto se distribua esparsamente por quase toda a área escavada, concentra-se, em termos de repartição espacial, na área oriental do sítio, na envolvente das grandes estruturas de combustão (e até no interior destas, como é o caso da EC2-L3), e, bem assim, no espaço que medeia entre umas e outras (Figura 3). Tal evidência indica suplementarmente que aquelas estruturas de realização de fogo, e das atividades que se lhe associam, polarizam efetivamente a vida rotineira do grupo, e que a área principal do sítio arqueológico se situaria naquele espaço, pelo que calculamos que metade do habitat/acampamento terá sido destruído/"lavado" por fenómenos de deslocação sedimentar, pela ocupação posterior e particularmente pela construção da estrada, como atrás referimos. Mesmo assim, a distribuição e caracteristicas do material lítico talhado esclarece que a área em torno das EC1 e EC2 (com L3) - que forneceu quase metade do espolio lítico talhado - além das atividades rotineiras de um sítio de habitat (pois indica tratar-se de uma área multifuncional), destaca particularmente atividades de talhe/fabrico de utensílios, documentando-se aí todas as etapas das cadeias operatórias, particularmente em torno da Estrutura de Combustão 2 (Mendes, 2017, p. 50-53 e Anexo 3). Esse fabrico está mais parcamente documentado em torno da $\mathrm{EC}_{3}$.

Como instrumentos polidos destacamos os moinhos de granito (mormente moventes), e embora a maior parte deles se encontre partida, também se concentram, tal como ocorre com os líticos talhados, em torno da EC2- $\mathrm{L}_{3}-9$ moventes, dos quais 3 completos, um fragmento de dormente e mais dois fragmentos. Estes dois últimos serão indubitavelmente neolíticos já que foram reutilizados como elementos refratários no interior da EC2; os restantes, a par de um machado polido, poderão ter sido usados quer no Neolítico quer na I. do Bronze, embora a peça 178 - movente/bigorna - apele mais a um uso no Neolítico. Já o mesmo não podemos dizer dos elementos de adorno que interpretamos como neolíticos: uma conta de colar de arenito, esverdeada (do interior da Lareira 4), e do pendente oblongo em quartzito quase marmóreo, de cor cin- 
zenta/escura-negra (Figura 5), que jazia já sob uma pelicula de saibro, no que considerámos ser a base da cam. 2 (D 1o). Tratar-se-á, por certo, de objetos perdidos, embora nos custe aceitar a não recuperação do pendente, se atendermos ao esforço investido na sua conformação e polimento.

Surpreende a fraca quantidade de cerâmica, toda decorada, da cam. 3, pelo que cabe perguntar: a) só terá existido esta cerâmica? b) não se terá reconhecido no conjunto devido ao facto de a maioria da cerâmica deste sítio se encontrar muito deteriorada ${ }^{4}$ e de ser lisa, o que não permite a distinção "tipológica" clara entre a cerâmica do B. Final e daquela do Neolítico ? c) sendo um bem raro e transportável, refletiria a sazonalidade do habitat, e, ao mesmo tempo, o elevado valor social que lhe seria atribuído?

Nunca poderemos responder de modo simples, pois admitimos que, à semelhança de outros sítios da mesma cronologia da bacia do Douro e Norte de Portugal, a quantidade de cerâmicas, sendo sempre relativamente pequena (mas nunca inferior a centena e meia de fragmentos), só é quase pontual, como na Lavra I, em locais considerados de frequência sazonal e/ou naqueles que tem misturas com cerâmicas de outras épocas (Sanches, 2021, no prelo). Acresce que naqueles conjuntos, conquanto em proporções bastante variáveis, as cerâmicas (fragmentos) lisas preponderam sobre as decoradas - principalmente naquelas da região litoral, a ocidente da Padrela-Alvão-Marão (região biogeográfica atlântica e de transição) - pelo que a identificação pela tipologia decorativa é irrealizável. É o que pode ter acontecido em Lavra I onde, realmente, diversas formas - como aquelas de corpo com tendência em forma de saco ovoide/globular umas, e taças semiesféricas altas, outras (Mendes, 2017, 206, 208) - são tipologicamente admissíveis em ambos os períodos. Consta-se ainda que a área envolvente das EC1 e 2, tão rica em espolio lítico talhado foi aquela onde, de entre toda a estação, se exumou o mais reduzido número de fragmentos, o que concorreu para a reconstituição de três formas. De entre estas, somente a taça semiesférica poderá porventura ser "tipologicamente “associada à ocupação neolítica.

4. A Lavra I e II é uma estação que, atendendo à área escavada, tem pouco material cerâmico (6660 fragmentos), cuja fragmentação e deterioração permitiu a reconstituição formal de poucos (c. de 15) recipientes, estando os restantes indicados somente ao nível da inclinação do bordo e/ou do fundo (plano).
São já bem conhecidos os dois recipientes decorados com puncionamentos arrastados (K-L6) (Figura 5), havendo somente a reiterar que ambos revelam uma tendência para a organização em grinaldas, sendo que no vaso globular, a decoração puncionada de tipo boquique se organizou em função da decoração plástica (um mamilo), numa sequência operatória e organização decorativa que veremos adiante no vaso com decoração impressa da Bouça do Frade (Jorge, 1988, Fig. 43-3). Soma-se, de H6, cam.3, um pequeno bordo com incisões profundas (bordo denteado), e um fragmento de pança com incisões profundas e curtas, desenhando espiga, conhecida como de tipo folha de acácia.

\section{DISCUSSÃO E CONSIDERAÇÕES FINAIS}

Sintetizando o que atrás foi exposto, cabe destacar o que se segue.

O sítio de Lavra I ocuparia uma área em torno a $500 \mathrm{~m}^{2}$, apesar de as principais estruturas habitacionais escavadas no saibro - grandes estruturas de combustão, buracos de poste e paliçadas - indicarem uma polarização da vida rotineira do grupo ocupante na zona mais oriental, num espaço de cerca de $300 \mathrm{~m}^{2}$. Implanta-se, em termos topográficos e climáticos num ecótono, ou seja, num patamar intermédio da Serra da Aboboreira - 400-60o/70om: Terra de Transição - do qual é relativamente fácil aceder, em distâncias pedestre de entre 1 e $2 \mathrm{~h}$, a todos os ecossistemas de Terra Fria de Montanha; e igualmente aos vales mais baixos e temperados, abarcados numa distância pedestre máxima de ih. A sua cronologia que estabelecemos ter ocorrido, como limite mínimo, no intervalo de 490o/480o-450o cal BC $2 \sigma-$, situa a ocupação no Ótimo Climático Atlântico, e na sua periferia dominariam os bosques mistos, com destaque para o caducifólio (carvalhal, medronheiro), cujo elenco de frutos e tubérculos seria algo diversificado; conjugada com pequenas áreas abertas, de pastagem, haveria condições para a presença de animais de médio e pequeno porte. Nas terras baixas, além de recursos florestais mais termófilos, destacaríamos a pesca como possibilidade - ribeiras/ rios de Juncal/Galinhas/Ovelha e Tâmega por um lado, e Roupeira/Ovil/Douro, por outro (Figura 1). Deste modo, em termos de possibilidades oferecidas pelos ecossistemas envolventes, a Lavra I poderia ter sido um sítio de ocupação permanente - habitat permanente de curta duração, ou, alternativamente, 
habitat residencial — dada a facilidade de acesso à montanha - pastos de primavera-verão, caça, recoleção ou, quem sabe, alguns animais domésticos -, e ao aproveitamento mais contínuo, ao longo do ano, dos recursos da sua envolvente imediata e das zonas mais baixas.

Todavia, esta é somente uma das possibilidades baseada na localização e no investimento que as diversas estruturas habitacionais implicaram (particularmente as grandes estruturas de combustão), pois a má conservação da estratigrafia não autoriza a ilação de que se estivesse melhor conservada disponibilizaria, por ex., muitos mais instrumentos. Aqueles recolhidos indicam: atividades de moagem (provavelmente de bolota); fabrico de instrumentos líticos talhados cujas matérias primas se encontram, à exceção do sílex, na Serra da Aboboreira; caça, indiretamente assinalada pelas pontas; recolha de combustível proveniente talvez de velhos carvalhos e medronheiros já mortos e/ou sujeitos a queima para derrube. Por falta de conservação, estarão ausentes quaisquer vestígios de consumo de animais, e o uso alimentar de diversos frutos - bolota, medronho, pilrito - é deduzido do uso destas espécies arbóreas na EC2.

As atividades rotineiras, incluindo o talhe de instrumentos, centram-se em torno das grandes estruturas de combustão pelo que admitimos também que estas fossem limpas regularmente e usadas sempre segundo o mesmo modelo de aproveitamento do fogo (Figura 4). É-nos mais difícil aceitar que possam ter sido utilizadas uma só vez, o que daria ao habitat um caráter pontual. Assim, da conjugação dos diversos elementos expostos, inclinamo-nos mais para a ocupação permanente deste ecótono, admitindo, mesmo assim, que se tratasse de uma base residencial. Esta questão traz à colação a natureza do povoamento da Serra da Aboboreira, que, à semelhança do que Domingos Cruz defende também para o Alto Paiva, se parece manter com alterações pouco significativas até aos finais do $4^{\circ}$ mil. a.C. (Cruz, 2001, p. 300).

Percorrendo as diversas escavações realizadas na Aboboreira, destacamos oito sítios, sendo que seis deles são solos aprisionados sob as mamoas ${ }^{5}$ e dois são sítios de plataforma, localizados em cabeceiras

5. Contabilizamos somente aqueles com vestigios de ocupação, e não aqueles cujos solos enterrados tem datas absolutas de todo o $5^{\circ}$ mil. a.C., que são em número muito mais elevado. de formação de ribeiros: Lavra I e Penedos Altos (Sanches, 2021, no prelo). Estes têm a particularidade de se situarem em áreas com ocupações posteriores que, no caso de Penedos Altos (750 m), é temporalmente mais contínua do que na Lavra I pois a Bouça do Frade/Tapado da Caldeira tem cronologias pelo menos do Calcolitico ao B. Final (Jorge, 1988). O sítio dos Penedos Altos, escavado por Susana Oliveira Jorge, está ainda inédito, mas continha, segundo Domingos Cruz, que participou na escavação (Cruz,1992, 11-nota 90 e inf. pessoal), pequenas estruturas negativas alongadas (paliçadas?), e o material arqueológico era microlítico, destacando-se micrólitos geométricos. Situa-se numa das partes mais baixas, mas na zona aplanada, da Bouça do Frade, povoado que, como se sabe, está incompletamente escavado (Figura 1). Ora, precisamente da escavação deste povoado, do setor IIB (abaixo do estradão) (Jorge, 1988, 53 e Fig. 43-3) foram exumadas, entre outras cerâmicas mais tardias, 5 fragmentos de um recipiente cerâmico - uma taça alta, semiesférica ${ }^{6}$ - com decoração barroca, feita com impressão arrastada de pente convexo, simulando concha (Figura 5-B). Tem ainda um cordão - que se desenvolve também pontualmente em pega alongada - paralelo ao bordo. O lábio deste é profusa e cuidadosamente decorado no lábio e face exterior do bordo, com uma matriz curta, de ponta em arco. Comparando-os com os da Lavra I, destaca-se a organização decorativa em grinaldas, a decoração plástica e o bordo cuidadosamente decorado. Dada a grande mobilização de sedimentos nesta estação, é provável que, também aqui, outros fragmentos pertençam igualmente a uma ocupação mais antiga, mas que serão difíceis de destrinçar pela tipologia. Por seu lado, uma lamela retocada em sílex e, com mais reticências, um pequeno machado polido, provenientes dum setor a uma cota ainda mais baixa (S. IA) (Jorge, 1988: Fig. 36, no 5 e 6) talvez se possam associar a esta ocupação antiga, que atribuímos ao Neolítico inicial regional. Ainda que se trate de um elemento pontual, deve ser valorizado, neste contexto, o fragmento cerâmico com decoração boquique (organização em grinaldas) da Mamoa de Furnas 2 ( 850 m dealtitude) (Figura 1), atribuído a um povoado próximo, prévio à construção do tumulus,

6. Tendo sido a autora do desenho, considerei que o pequeno fragmento do bordo só autorizava a inclinação, mas não o diâmetro. 
que teria ocorrido no último quartel do $5^{\circ}$ mil. a.C. (Sanches, 2012, no prelo).

Como hipótese, teríamos então a ocupação neolítica da Aboboreira, numa fase mais antiga- centrada na $I^{\underline{a}}$ metade do $5^{\circ}$ mil. a.C. - com habitats em diversos ecossistemas - patamares altimétricos dos 620 aos 850 m (Figura 1) -, onde circulariam cerâmicas bastante decoradas com impressões /matrizes diversas, plástica e incisa (folha de acácia), em contextos com material lítico microlítico, sendo algum deste em sílex.

Todavia, tomando o conjunto dos habitats da Aboboreira no alargado período que cobre todo o $5^{\circ} \%$

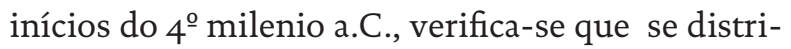
buem, afinal, por todos os patamares altimétricos da Serra: entre 500-70o metros - Mamoa da Lavra, Lavra I, Chã de Santinhos 2; de 700 a 900 m - Penedos Altos, Mamoa de Cabras, Mina do Simão, Furnas 2; $940 \mathrm{~m}$ : Meninas do Crasto 2 (Sanches, 2021 e bibliog. aí citada, no prelo) (Figura 1). Esta distribuição, por certo muito residual relativamente ao número dos primitivos habitats, parece mostrar um padrão de ocupação da Aboboreira que perdura no tempo, ou seja, coincide também com o da construção dum elevado número de mamoas, a maioria contendo dolmenes simples - entre c. de $4500 / 4300$ e 3800 cal BC 2 o (Cruz 1992; 2001). Porém, tal como tem vindo a ser apontado por Domingos Cruz, existem nesta necrópole dados antes não devidamente valorizados - relativos a algumas das mamoas muito pequenas e baixas, camufladas na paisagem ${ }^{7}$, (podendo não conterem câmaras megalíticas, mas somente um pilar/esteio ao centro, como acontece em Monte Maninho e Cabras) - cuja cronologia de fundação abrange o $2^{\circ}$ e $3^{\circ}$ quarteis do $5^{\circ}$ mil. a.C. Destaca-se neste conjunto a Mamoa de Monte Maninho por distar cerca de 1,4 Km da Lavra I (Cruz, 1988), por estar situada no mesmo patamar altimétrico, e dela se terem obtido duas datas estatisticamente semelhantes, cuja media ponderada é de 4770-4503 cal BC 2 o (Cruz, 2001, p. 303, nota 191).

Este elo de ligação entre os habitats mais antigos e os monumentos mais antigos é apelativo e tem implicações não somente ao nível da caraterização socio económica e ideológica destes grupos do Neolítico inicial desta região - que apresentariam, cremos, uma grande mobilidade logística - e a fixa-

7. Monte da Olheira (com pequena câmara ortostática); Cabras e Monte Maninho ção, em definitivo, de lugares específicos dos seus territórios através de tumuli muito pequenos. Estes articular-se-iam com a identificação da ancestralidade - naqueles relacionados com enterramentos ou cerimónias fúnebres -, com práticas coletivas relevantes que podiam ocorrer de modo repetitivo no mesmo local, ou mesmo com ambas.

Dado que o modelo de implantação dos habitats no Neolitico inicial (até meados do $5^{\circ}$ mil. a.C.) e do Neolítico médio (até ao $1^{\circ}$ quartel do $4^{\underline{0}}$ mil. a.C.) se parece manter, existirá então uma relação espacial muito estreita entre os locais de vida rotineira e aqueles que não só concatenam, mas agenciam, através das arquiteturas duráveis, os aspetos mais relevantes da reestruturação social e ideológica. Essa relação inaugura-se no $2^{\circ}$ e $3^{\circ}$ quartéis do $5^{\circ}$ milénio a.C. No seu conjunto, os oito habitats, ainda que vistos pela pequena fração conservada, tem estruturas habitacionais perecíveis, formadas por fossas (pequenas), buracos de poste, alguns valados ou paliçadas e sobretudo lareiras, nas quais se destacam as da Lavra I pela sua desmesurada dimensão. Têm pouco material arqueológico, sendo dominante o lítico talhado, atípico, de tendência microlítica, maioritariamente em quartzo filoniano, mas também surge em quartzo hialino e sílex. Nos mais antigos não se registam machados, mas antes moinhos de granito e seixos de rio, ambos frequentemente partidos. Também não se encontram adornos, a não ser em Lavra I. Relativamente à cerâmica, já falamos dos que consideramos poderem ser mais antigos. Naqueles com cronologias aproximadas da $2^{\underline{a}}$ metade/ último quartel do $5^{0}$ milénio a.C. - que são o total à exceção de Chã de Santinhos 2 - a cerâmica, sempre mal conservada, tem formas muito diversas, sendo a maioria lisa; a decorada integra-se, pela singeleza, noutros (raros) conjuntos ceramológicos de habitats da região biogeográfica atlântica da bacia hidrográfica do rio Douro, datados (ou datáveis) de todo o $5^{\circ}$ mil. a.C. (Sanches, 2021 e bibliog. aí citada, no prelo).

Se nos casos que estamos a analisar a complexidade decorativa de algumas cerâmicas indica antiguidade $-1^{\underline{a}}$ metade do $5^{\circ}$ mil. a.C., ou, talvez, finais do $6^{\circ}$ e primeira metade do $5^{\circ}$ milénio, caso consideremos o intervalo de 5200-4800 cal BC de sobreposição de todas as datas da Lavra -, igualmente aponta outras interpretações de caráter organizacional e ideológico. A sua raridade pode indiciar serem agentes de interação particular entre grupos de pequena dimensão - com fronteiras territoriais muito fluidas 
- em circunstâncias de dádivas, trocas, etc. Todavia, podemos estar a ser conduzidos por visões muito apriorísticas já que, afinal, cerâmicas decoradas com outros motivos e igualmente as não decoradas, podem ter cumprido funções similares no mesmo período (Sanches, 2021, no prelo).

Como diversos autores, através de trabalhos sérios e sistemáticos, tem referenciado, as cerâmicas estão quase ausentes das deposições dos dolmenes e mamoas do Norte de Portugal e Galiza da $2^{\underline{a}}$ met. do $5^{\circ}$ mil. a.C. Na Aboboreira surgem, outrossim, com mais frequência (por esta ordem) moinhos, seixos e cristais de quartzo, micrólitos geométricos e/ou lamelas (em silex e quartzo hialino), lascas/raspadores, objetos de adorno (em variscite e xisto), algumas enxós (pequenas, em corneana e silimanite), machados, raspadeiras, "artefactos" que evidenciam também, entre outras interpretações, a complexidade de relações entre segmentos sociais destes pequenos grupos e sua correlação quer com outros, quer com o território. Se num certo registo podemos argumentar que os espólios das mamoas se referem polissemicamente tanto a categorias do território e das pessoas envolvidas, como às atividades que evocam, no caso da Lavra I, e porventura dos Penedos Altos, seria o habitat o polo aglutinador da vida social e ideológica. Tanto pelas estruturas habitacionais de congregação coletiva, como pela presença, apesar da destruição, de objetos de adorno e de uma quantidade considerável de material lítico talhado, onde pontua o sílex (e o arenito). Mesmo tendo em conta a documentação fragmentaria que se conservou, nenhum dos restantes habitats soterrados pelas mamoas, datados de meados do $5^{\circ}$ milénio em diante, vai exibir tal diversidade, verificando-se antes um certo "deslocamento" desses materiais, à exceção da cerâmica, para as práticas coletivas ligadas às mamoas, sejam dominantemente de caráter fúnebre ou não.

Como argumenta J. Thomas (2015, p. 3), não existe na Europa Atlântica uma identidade social homogénea "mesolítica" ou "neolítica", quer argumentemos com a socio economia - proporção relativa das atividades subsistenciais, mormente das produtivas -, quer com os artefactos - sua natureza e proporção relativa -, quer ainda com as modalidades do povoamento, já que todos estes elementos surgem em combinatórias regionais muito variáveis e que vão sendo reconfiguradas ao longo do tempo. O que se verificará, no tempo longo é a tendência para o aparecimento de novas "entidades" no seio das comunidades de caçadores recolectores mesolíticos, que são criadas e manipuladas culturalmente de modo cada vez mais assertivo e estável já que os códigos dos recolectores são absolutamente contrários aos dos produtores (Thomas, 2015, p. 8-11). Se os animais domésticos, os produtos cultivados, os novos artefactos "utilitários" ou "não utilitários", implicam, é certo, uma crescente transformação das relações das pessoas entre $\mathrm{si}$ - criação progressiva de novas unidades sociais e reconfigurações da propriedade coletiva -, o que será igualmente de enfatizar é o facto de as relações entre humanos serem cada vez mais operacionalizadas através de "não humanos", sustidas por não-humanos e mesmo delegadas e esses não-humanos", entidades que são incluídas no entrosado das relações sociais, num contexto de fronteiras mais marcadas (Thomas, 2015: 10).

No caso da Serra da Aboboreira, inserida na região biogeográfica atlântica, mas também no de toda a baixa bacia do Douro, têm particular sentido os estudos dos processos históricos que regionalmente conduziram às transformações que se verificam no tempo longo, do $7^{\circ}$ ao final do $4^{\circ}$ mil. a.C., não sendo esse o objetivo deste texto. Mas, mesmo assim, insistimos em que as redes sociais amplas e as fronteiras territoriais ainda fluídas do $6^{\circ}$ e $5^{\circ}$ mil. a.C. onde circulam pessoas e artefactos, incluindo animais domésticos e produtos cultivados (e suas sementes), teriam proporcionado trocas/ofertas esporádicas, ou mais frequentes, realizadas por certo segundo os códigos dos caçadores recolectores dos inícios do Holoceno, de que existem alguns habitats e numerosos sítios com arte rupestre (Sanches, 2021 e bibliog. aí citada, no prelo). A inclusão dessas "coisas" nos parâmetros socioeconómicos e ideológicos dos grupos é espacial e temporalmente muito variável, mesmo entre comunidades vizinhas (Monteiro-Rodrigues, 2011). Embora não possa ser avaliada no seu pormenor devido a condições tafonómicas, regista-se uma tendência para a presença mais generalizada de alguns artefactos móveis (cerâmica e moinhos), animais (ovelhas ou cabras) e cereais em datas mais antigas (desde meados do 6º milénio a.C.) (López-Sáez et al., 2017), na região biogeográfica mediterrânica da bacia do Douro, onde se conecta com arte rupestre (Sanches, 2021, no prelo), ainda que, mesmo aí, a produção de alimentos de baixa escala pudesse ser ambientalmente e socialmente contingente. É provável que seja ainda neste contexto de grupos com fronteiras 
muito fluídas, porosas - por onde podiam circular pessoas a par de artefactos (Thomas, 2004) - que surgem cerâmicas, moinhos e materiais de sílex na Aboboreira (Lavra I e Penedos Altos), segundo a tradição dos caçadores recolectores mesolíticos longamente estabelecidos. Todavia, as mamoas ao começarem a marcar de modo mais estável, sobretudo na fase mais antiga (a partir do $2^{\circ}$ quartel do $5^{\circ}$ mil. a.C.), áreas de pastos, talvez estejam a integrar novas entidades ideológicas - os animais domésticos (cujos restos não se conservaram) -, na definição de novos grupos sociais, onde se articulariam com outras entidades evocadas pelos seixos, cristais de quartzo, micrólitos, lamelas, mas também moinhos, enxós e menos com machados e cerâmicas.

\section{AGRADECIMENTOS}

A autora pertence ao Grupo de investigação Territórios e Paisagens do CITCEM, inserindo-se este trabalho no projeto UIDB/04059/2020 da FCT Fundação para a Ciência e a Tecnologia.

Agradece-se a Joana Teixeira, Rafael Morais e Cláudia Manuel a colaboração nas imagens e a Domingos Cruz a assertiva e viva troca de opiniões (e cedência de documentação inédita). De qualquer modo, as opiniões expressas são exclusivamente da nossa responsabilidade.

\section{BIBLIOGRAFIA}

CRUZ, Domingos J. (2001) - O Alto Paiva: Megalitismo, Diversidade Tumular e Práticas Rituais Durante a Pré-história Recente, 2 vols., Universidade de Coimbra.

CRUZ, Domingos J. (1992) - A Mamoa I de Chã de CarvaIhal no Contexto Arqueológico da Serra da Aboboreira e da Pré-história Recente do Norte de Portugal. Coimbra: Instituto de Arqueologia da Universidade de Coimbra.

CRUZ, Domingos J. (1988) - Escavação da Mamoa de "Monte Maninho". In Trabalhos de Antropologia e Etnologia. Porto. 27:14, p. 65-84. Muito perto da Lavra; iguais datas LÓPEZ-SÁEZ, José A.; ABEL-SCHAAD, Daniel; IRIARTE, Eneko.; ALBA-SÁNCHEZ, Francisca; PÉREZ-DÍAZ, Sonia; GUERRA-DOCE, Elisa; DELIBES de CASTRO, Germán; ABARQUERO MORAS, Javier, 2017, Una perspectiva paleoambiental de la explotación de la sal en las Lagunas de Villafáfila (Tierra de Campos, Zamora), Cuaternario y Geomorfología (2017), 31 (1-2), 73-104.

LÓPEZ SÁEZ, José A.; FIGUEIRAL, Isabel e CRUZ, Domingos J. (2012) - Palaeoenvironement and vegetation dynamics in serra da Nave (Alto Paiva, Beira Alta, Portugal) during the Late Pleistocene and Holocene, Estudos Pré-históricos, 17, CEPBA, Viseu, pp.11-24.

MENDES, Cátia M. (2017) - O Povoado pré-histórico da Lavra - Serra da Aboboreira. Contributos para o estudo do Neolítico antigo e do Bronze Final no Norte de Portugal. Dissertação de Mestrado, FLUP.

MONTEIRO-RODRIGUES, Sérgio (2011) - Pensar o Neolítico Antigo. Contributo para o Estudo do Norte de Portugal entre o VII e o Vmilénios a.C., [Estudos Pré-históricos, 16.] Viseu: Centro de Estudos Pré-históricos da Beira Alta.

RAMIL REGO, P.; GÓMEZ-ORELLANA, L. \& MUÑOZ SOBRINO, C. (2010) - Cambio climático durante el último ciclo Glaciar-Interglaciar en el NW Ibérico. In BETTENCOURT, Ana; ALVES, Isabel\&MONTEIRO-RODRIGUES, Sérgio, eds.- Variações Paleoambientais e Evolução Antrópica no Quaternário do Ocidente Peninsular. Braga: APEQ/ CITCEM: 23-38.

SANCHES, Maria (2021, in press) - Current remarks on the neolitization of the Lower Douro basin and Northern Portugal. In GUERRA-DOCE, Elisa, ed., O Neolitico Interior. Univ. de Valladolid.

SANCHES, Maria (2003) - Sobre a ocupação do Neolítico inicial do Norte de Portugal. In GONÇALVES, Victor, ed.- Muita Gente, Poucas Antas? Origens, Espaços e Contextos do Megalitismo. Trabalhos de Arqueologia, 25, IPA, pp. 155-179.

STOCKLER, Carla (1998) - Em torno da cronologia do megalitismo da Serra da Aboboreira: novas datas de Carbono 14 da mamoa das Cabras (Amarante), Estudos Pré-Históricos. Viseu. 6, pp. 167-173.

THOMAS, Julian (2015) - What do we mean by 'Neolithic Societies'? In: FOWLER, Chris; HARDING, Jan \& HOFMANN, Daniela, eds. The Oxford Handbook of Neolithic Europe. Oxford: Oxford University Press, pp. 1-22.

THOMAS, Julian (2004) - Current debates on the Mesolithic-Neolithic transition in Britain and Ireland. Documenta Praehistorica, XXXI, pp. 113-130. 


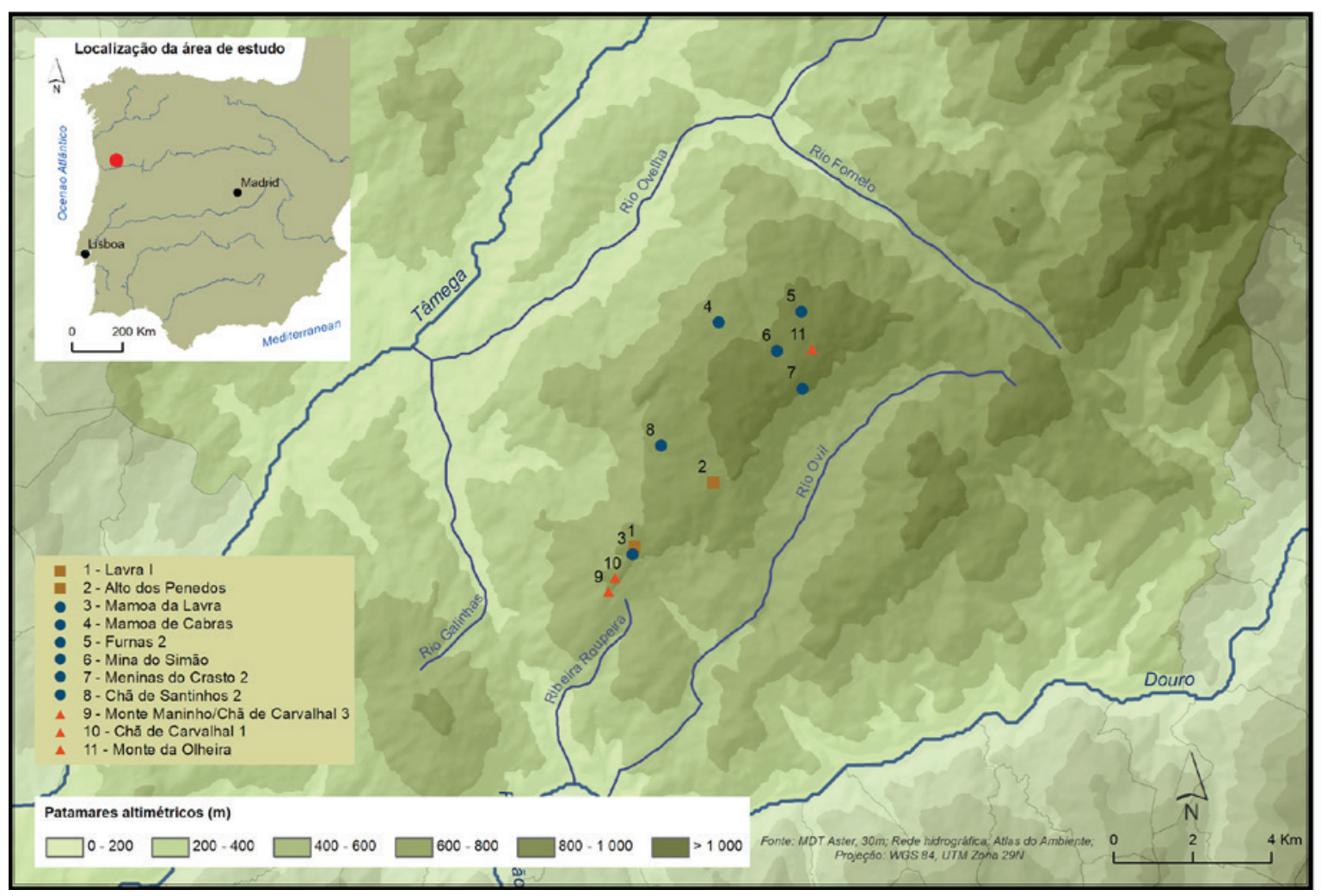

Figura 1 - Serra da Aboboreira (entre os Rios Ovelha e Ovil) e sua referência geográfica à Península Iberica. 1-2 (quadrados) - habitats; 3-8: habitats sob mamoa (círculos); 9-11: outras mamoas referenciadas no texto (figura elaborada por Cláudia Silva).

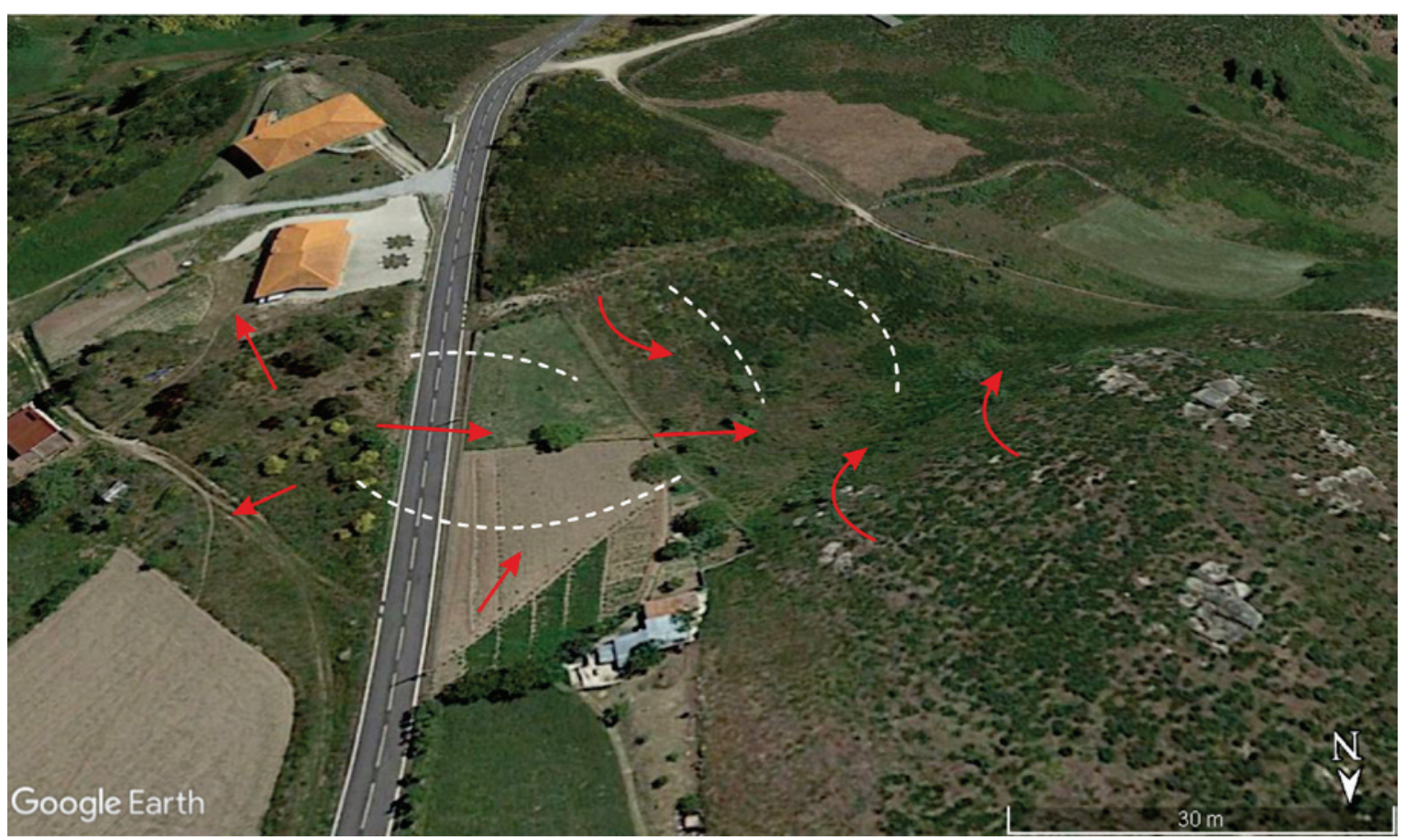

Figura 2 - Lavra e representação esquemática da sedimentação dominante (deslocação sedimentar indicada pelas setas vermelhas). As principais estruturas habitacionais de Lavra I encontram-se entre as duas linhas curvas, sobre a estra$\mathrm{da}$, aproximadamente sob a seta central, vermelha (figura elaborada por Rafael Morais). 

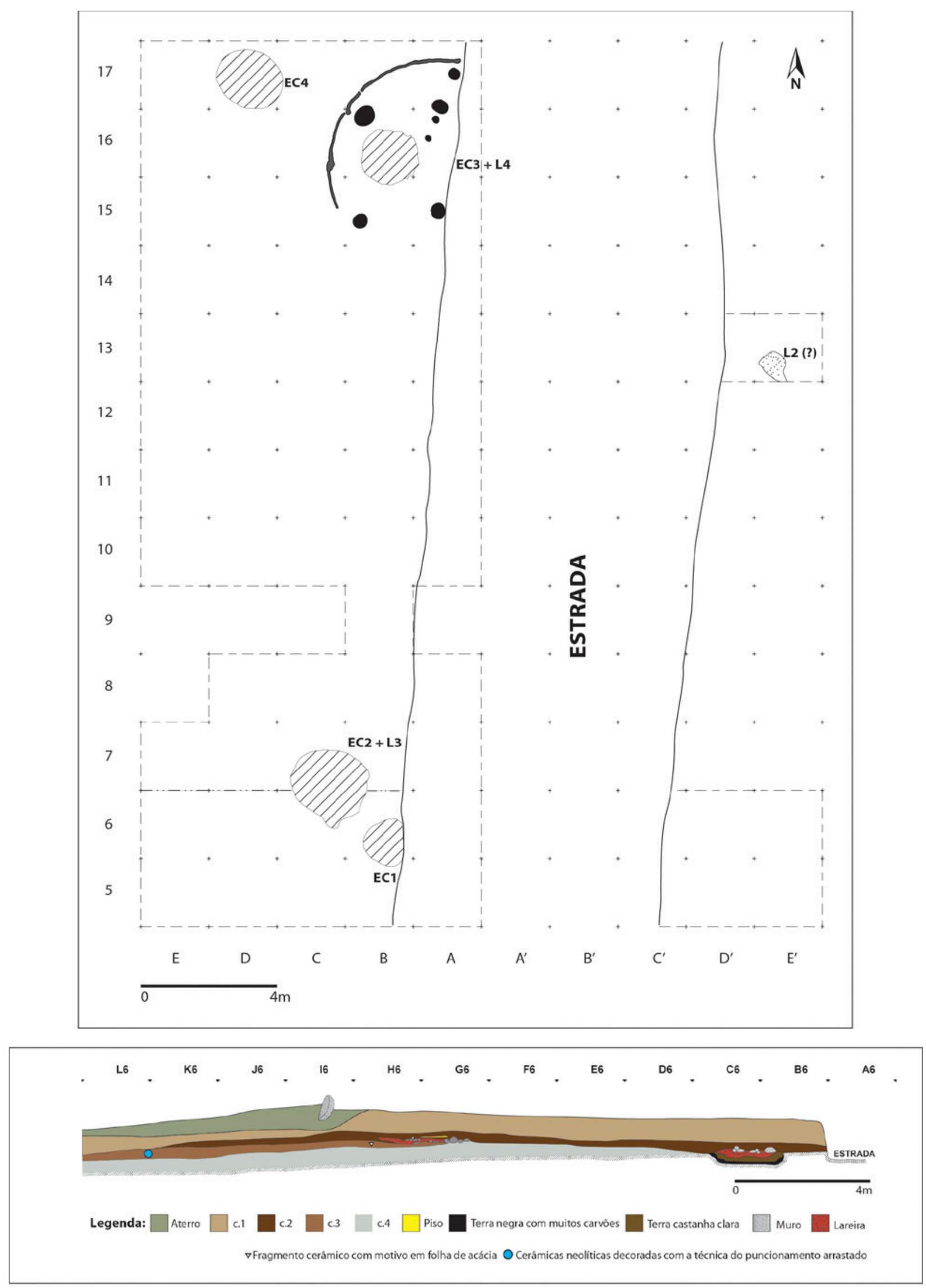

Figura 3 - A - Lavra: planta esquemática da área com estruturas. B - corte estratigráfico (ver sua marcação na planta). A estratigrafia é descrita em texto (figura elaborada por Joana Teixeira). 


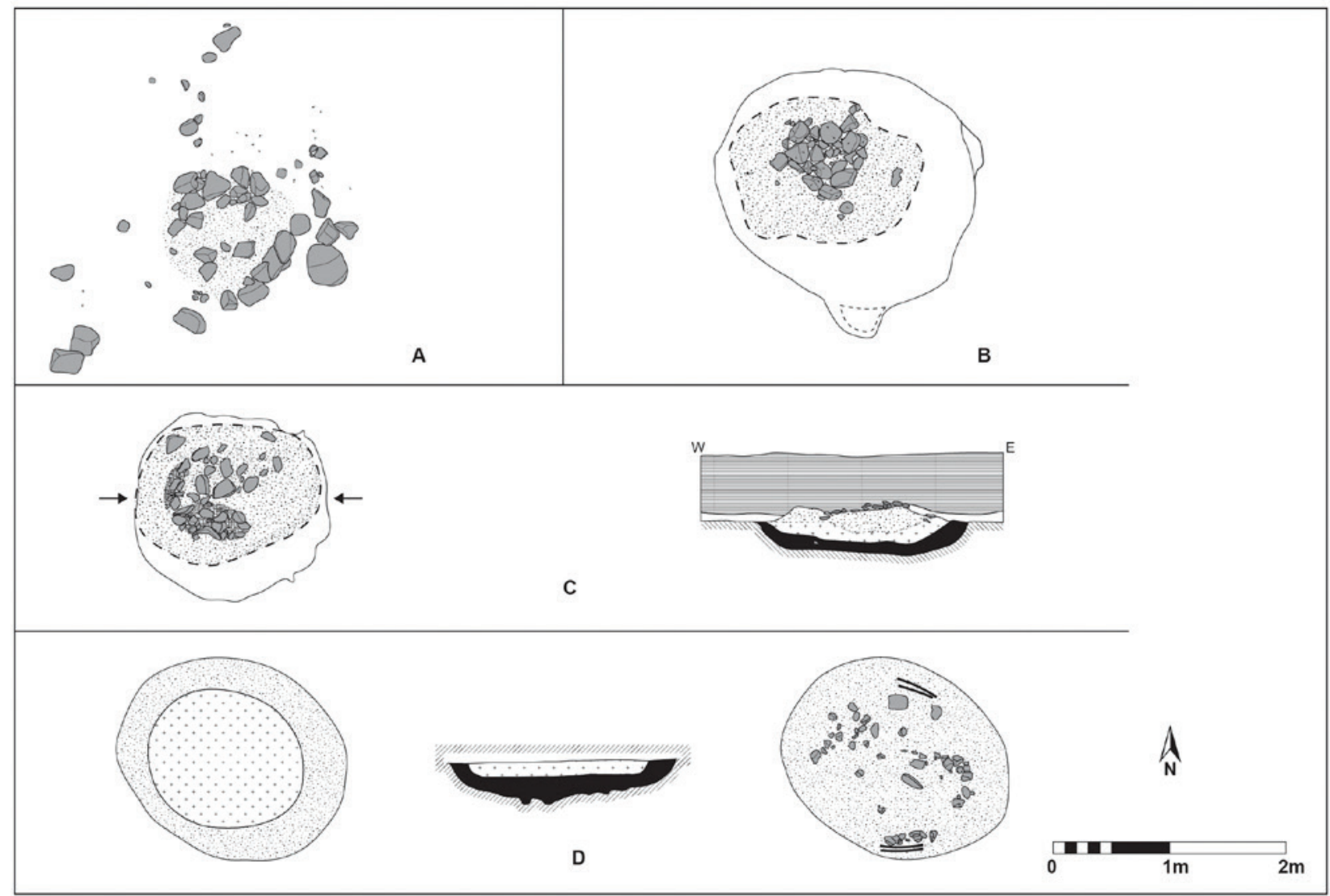

Figura 4 - Lavra I: Estruturas de Combustão. A e B - Lareira 3 (dois planos) tendo marcado, em B, o contorno da Estrutura de Combustão 2 (que lhe subjaz). C - Lareira 4 tendo marcado o contorno da estrutura de Combustão 3 (que lhe subjaz), e respetivo corte estratigráfico. D - Estrutura de Combustão 4: à esquerda no plano do seu topo, à direita no plano do topo da camada contínua de terra queimada e carvão (representam-se dois grandes troncos queimados). Ao centro, o respetivo corte estratigráfico. A estratigrafia encontra-se no texto (figura elaborada por Joana Teixeira). 


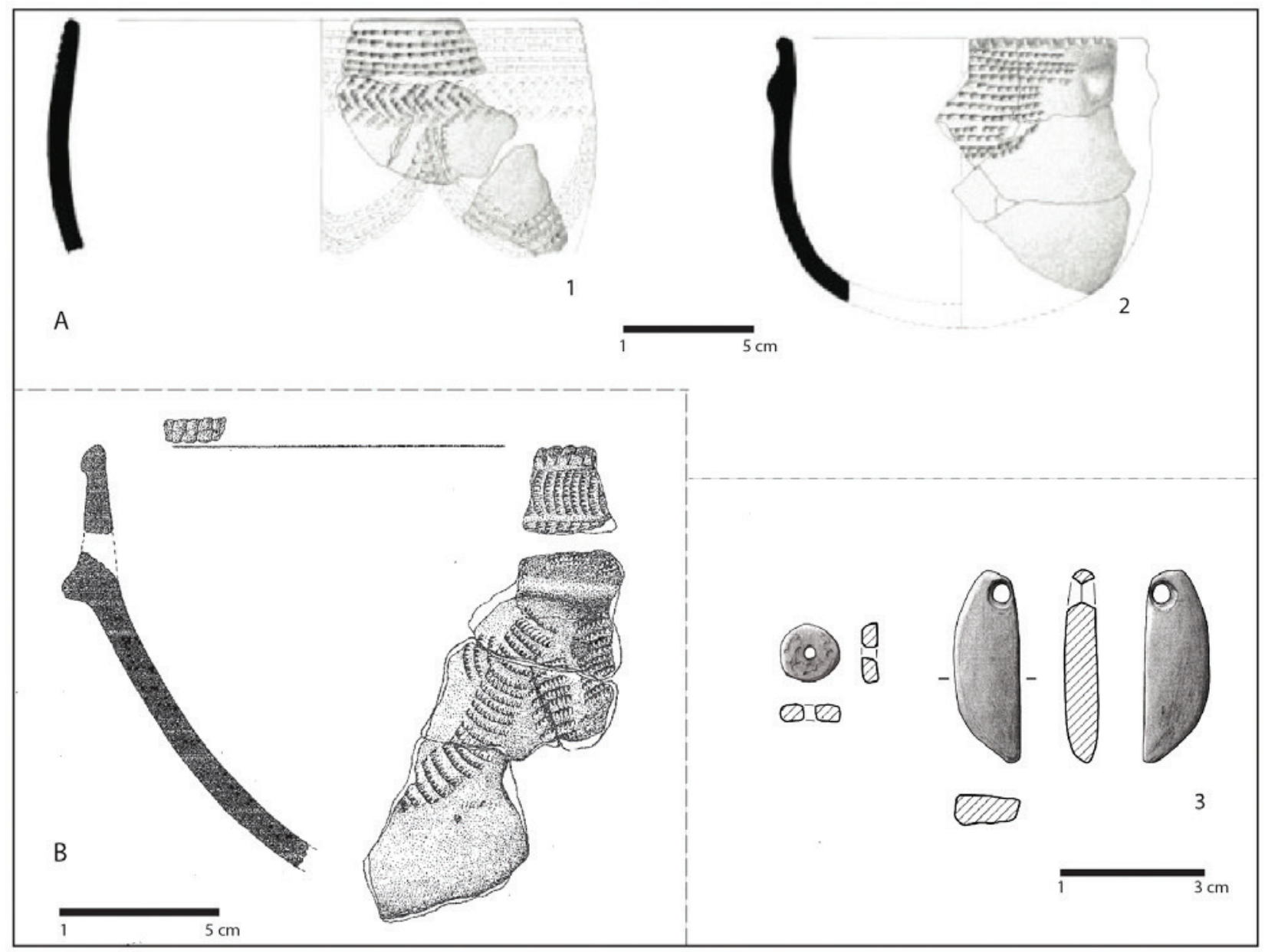

Figura 5-A - Recipientes cerâmicos (1, 2) e objetos de adorno (3) de Lavra I. B - Recipiente cerâmico de Alto dos Penedos (seg. Jorge, 1988, Fig. 43-3, adaptado) (figura elaborada por Joana Teixeira). 



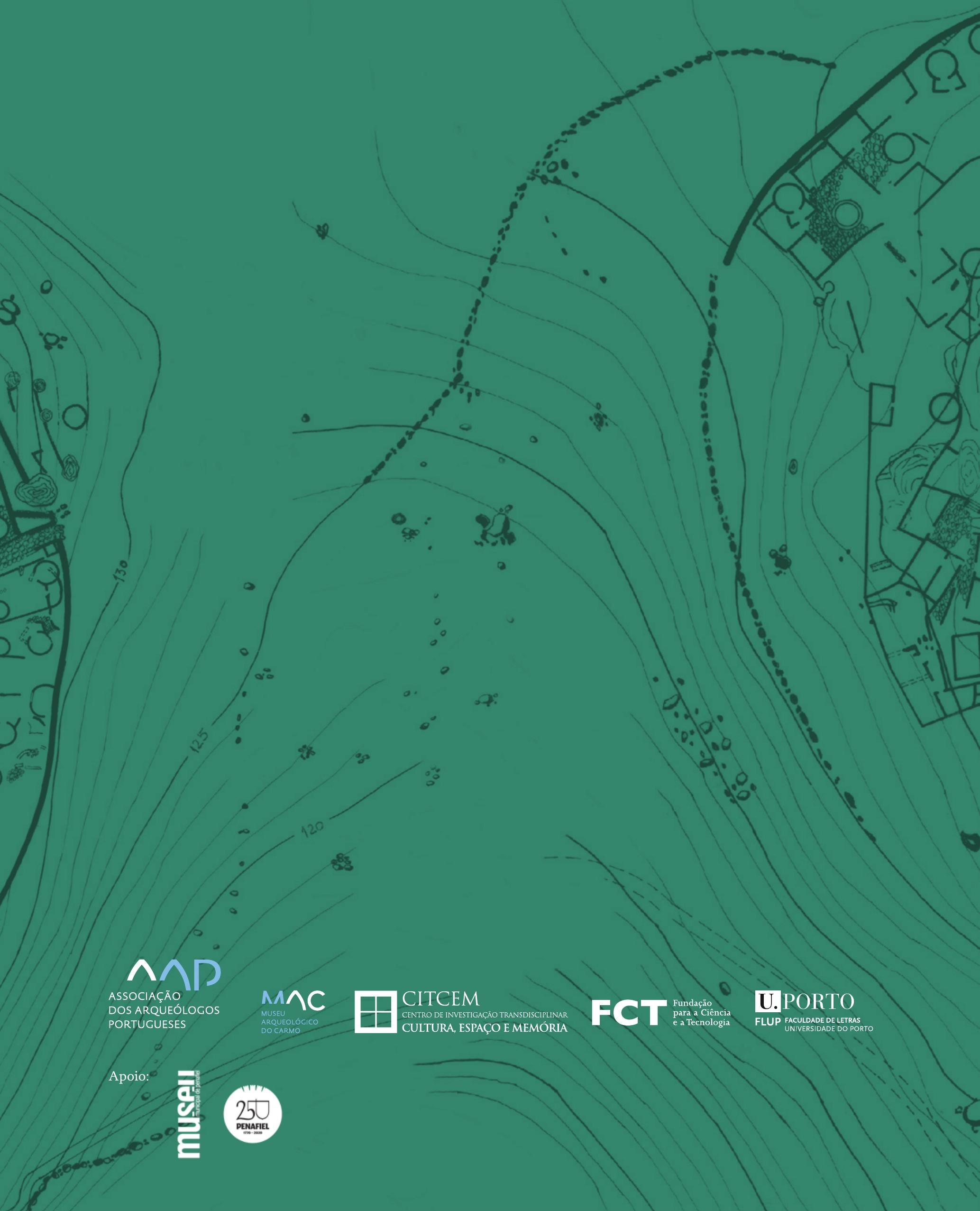

